\title{
MINORITIES RIGHT TO POLITICAL PARTICIPATION UNDER THE FDRE CONSTITUTION: SAVING THE PLIGHTS OF ETHNIC MINORITIES IN A MULTIETHNIC CITY (HAWASSA)
}

\author{
Anteneh Gezahegne Negash (LL.B, LLM) \\ Lecturer Masters of Law (LLM), School of Law, Wolkite University, Wolkite Ethiopia
}

\section{Table of contents}

Contents

Table of contents

Abstract Error! Bookmark not defined.

Acronyms . 111

Part I

1.1 Conceptualization of Political Participation in General: With Some Points in Reference to Minorities .113

1.1.1 Conceptualization of the Right to Political Participation .113

Part II 116

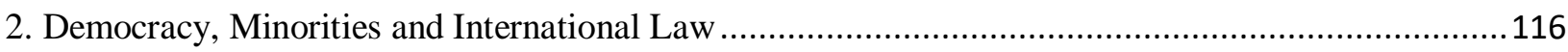

2.1 The Rights to Political Participation of Minorities under the UN and European System

2.1.1 The Political Participation of Minorities in the UN System: The Right to Political Equality under the UDHR and ICCPR

2.1.2 The UN Declaration on the Rights of Persons Belonging to National or Ethnic, Linguistic or

Religious Minorities (UNDM)

2.2 The Rights to Political Participation of Minorities under the European System: The European Convention on Human Rights

2.2.1 The Framework Convention on the Right of National Minorities

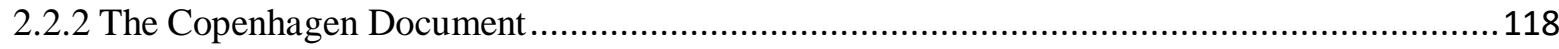

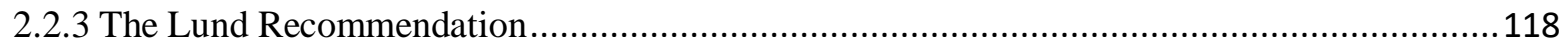

2.3 Minority Inclusion under Different Models of democracy........................................................119

2.3.1 Political Participation of Minorities under Procedural Democracy ...................................... 119

2.3.2 Political Participation Mechanisms for Minorities ................................................................... 119

2.3.2.1 Adequately Devised Election System...................................................................... 119 


\section{International Journal of Education and Social Science Research}

ISSN 2581-5148

Vol. 3, No. 02; 2020

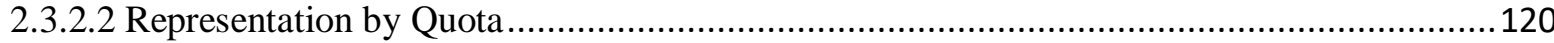

2.3.2.2 Political Parties and Minority Participation .................................................................. 120

2.3.2.2 Informal Channels of Participation: the Case of Advisory Bodies .....................................120

2.4 Moving beyond the Frontiers of Procedural Democracy: the road to hasten minority inclusive government

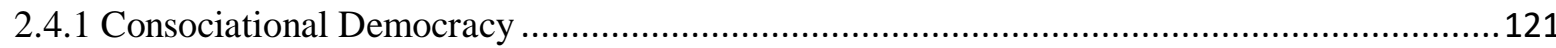

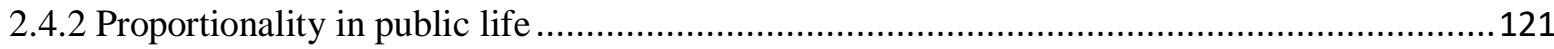

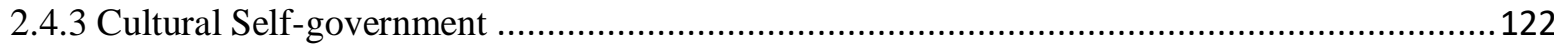

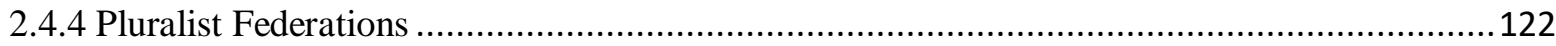

2.5 Political participation under the Consociationalist Design: Macedonian Municipalities as an example 122

Part III 123

3.1.1 Defining the Respective Concepts: who are indigenous peoples? ........................................123

3.1.1.1 Who can be accounted for the definition of Minorities? ................................................124

3.1 .2 Hammering on the Difference between the two Groups under International Law ...............125

3.1.2 The Rights of Minorities under International Law: what are the specific content the rights? .....126

3.1.2.1 Specific Contents of Minority Rights under International Law: .....................................127

Part IV 130

4. The Right to Political Participation under the FDRE Constitution: With Particular Reference to the Multiethnic Cities in Ethiopia 130

4.1 The Right to Equitable Representation under the FDRE Constitution (the Case of Collective Right) 131

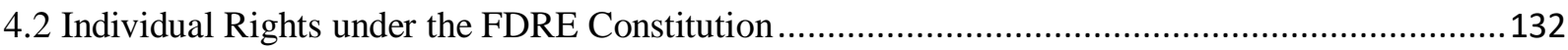

4.3 Political Participation in the Case of Multiethnic Cities in Ethiopia...........................................132

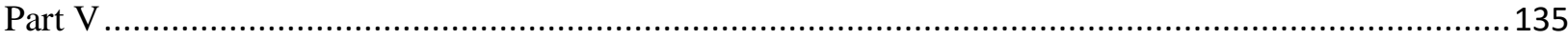

5. The Right to Political Participation under the SNNP Constitution: the Case of Hawassa City Administration 135

5.2 The Practical Aspects of political participation and Power Sharing in Hawassa City Executive and

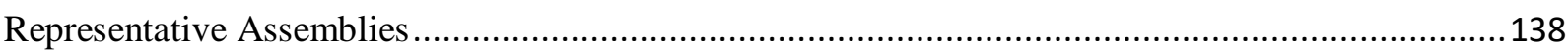

5.2.1 General Background of the Hawassa City Administration: A brief Analysis ........................138

5.2.2 The Political Participation of Minorities in Hawassa City Council and the Executive Branches 140

5.2.2.1 The Protection of Individual Rights ........................................................................ 140

5.2.2.1.1The Individual's Right to Employment in the City Civil Service Sector..........................140 


\title{
International Journal of Education and Social Science Research
}

ISSN 2581-5148

Vol. 3, No. 02; 2020

5.2.2.1. The Right to Political Participation and Power Sharing at the City and Kebele Councils...142

5.2.2.2.1. In the City and Kebele Councils 143

5.2.2.2.1.1 The Right to Power Sharing and Political Participation in the Kebele Councils 149

5.2.2.2 in the City and Kebele Executive Organs: a City Geared under a Homogenous Executive 150

5.2.3 Enhancing the Ethno-Symbolic Attachment of the Sidamas in their Traditional City 153

Part VI 154

6.1 Conclusion and Recommendation 154

BIBLIOGRAPHY 160

Interviews, Annexes and Others 166

\begin{abstract}
This paper investigated whether the FDRE constitutions has clear legal standards so that regional constitutions can emulate in their endeavor, if any so far, to ensure the realization of the right to political participation as well as the right to promote and protect identity rights by the nonindigenous groups, who are currently co-habiting with the regionally empowered indigenous groups. Of course, the function of this legal standard, if it exists, beyond assuring those rights for the nonindigenous groups at the same time it is also required to guarantee that the exercise of the same right by the indigenous groups remain intact.
\end{abstract}

The analysis of the paper reveal that because of failure on the part of the FDRE constitutions to envisages clear legal standards for the aforementioned urgent task has resulted in nothing but, in the disfranchisement of the majorities of the urban dwellers from partaking in the conduct of public affairs. To explain this a little bit, in the regional states dominated by the titular groups such as Oromia, because of the adaption of the language of the empowered ethnic group as the language of government business, the non-indigenous groups' rights to political participation has been effectively curtailed. In conforming to this Yonatan also argue that this has yielded in the disenfranchising a large number of the population in most urban areas of the different regional states from partaking in the conduct of public affairs. This undermines the constitutional commitment to equal respect for individual and group rights. That is why it is said that the major limitation of the federal system is that it does not adequately address the plight of ethnic migrants in terms of the right to use their language for government business. Therefore, corollary to this while the writer recommending the designing of legal standards for the alleviation of the gloomy situation, he notifies any move in this frontiers should strike a balance that would accommodate the same interest harbored by the so-called the indigenous ethnic groups in particular in urban cities where the number of the non-indigenous groups far more greater than the latter. 


\section{International Journal of Education and Social Science Research}

ISSN 2581-5148

Vol. 3, No. 02; 2020

In the multiethnic Cities of Hawassa, as the analysis of the paper unequivocally speaks, though the decision taken by the regional council in 2002 confers a right for the ethnically mixed urban dwellers (i.e. non-indigenous groups ) to equally partake in the governance of the city, thereby entailing them the corridor for political participation in the city executive and legislative councils as well as in the civil service Sector, absence of a legal scheme devised in detail to institutionalize power sharing ( i.e. non- allocation of executive seats for each ethnic residents pro-rata to the population size each group commands in the city via the introduction of proportional electoral system, while in mean time reserving considerable seats for the Sidama's in both councils) in those institutions has produced unwanted results namely; the dominance of the city governance by a single indigenous group ( identified as indigenous group in this paper due to the possession of indigeneity character in the view of the writer ) Sidamas. On the part of the indigenous group Sidama too, there is insecurity of being exposed to out numbering and out outvoting in lieu of the opening up policy followed by the regional council (the governance of the city by all segments of the ethnic dwellers of the city) and untrammeled migration of internal migrants from the adjacent zones.

In due cognizance of the aforementioned problems encountered Hawassa City, but a kind of problem exhibited elsewhere too where cities located under the self-determination rights of the titular groups are facing, the tasks a head for the SNNP Regional Council are so tough that it is urgently required to institutionalize power sharing through detailed law by taking the federal standards to be mapped for country wise as reference point.

The schemes to be designed for this purpose shall strike out the balance between the quest of the Sidamas peoples for preferential treatments because of their indigenousness in terms of political participation and promotion of their language and culture in the city as well as the desires of the city majority (the non-indigenous groups lumped together) for equal consideration in the power arrangements. If the federal government does not move forward to set forth the milieu and linchpin necessary for regional constitutions to take into account, while designing legal devises for the governance of the multi ethnic cities located under their peripheral limits, the regional councils shall contemplate the designing of legal touchstones via taking into consideration the way forwards and foreign experiences dwelled in this paper as part of their of residual power.

KEYWORDS: Indigenous and Non-indigenous Ethnic Group (community), Consociational Democracy, minority and multi-ethnic city

\section{Acronyms}

EPRDF Ethiopia People's Revolutionary Democratic Front

ECSC Ethiopian Civil Service College

FDRE Federal Democratic Republic of Ethiopia 


\section{International Journal of Education and Social Science Research}

ICCPR International Covenant for Civil and Political Rights

ICESCR International Covenant for Economic Social and Cultural Rights

OSCE Organization for Security and Cooperation in Europe

WWח World War the Second

UN United Nations

UDHR Universal Declaration of Human Rights

PCIJ Permanent Court of International Justice

FDRE Federal Democratic Republic of Ethiopia

Procl. No. Proclamation Number

HoF $\quad$ House of Federation

SNNPRS Southern Nations, Nationalities and Peoples Regional States

OPDO Oromo People Democratic Organization

ANDM Amhara National Democratic Movement

FDRE Federal Democratic Republic of Ethiopia

CoN Council of Nationalities

SEPDM Southern Ethiopia People Democratic Movement

TGE Transitional Government of Ethiopia

TPLF Tigrayan Peoples Liberation Front

UDHR United Nations Declaration of Human Rights

UNGA United Nations General Assembly

UNDM United Nation Declaration on the Rights of Persons Belong to National or Ethnic, Linguistics or Religious Minorities

ECHR European Convention on Human Rights and Fundamental Freedoms

FCNM Framework Convention on the Right of National Minorities 


\section{International Journal of Education and Social Science Research}

ISSN 2581-5148

Vol. 3, No. 02; 2020

$\begin{array}{ll}\text { W/t } & \text { Wizerit } \\ \text { W/r } & \text { Wizero } \\ \text { CSA } & \text { Central Statics Agency } \\ \text { E.C } & \text { Ethiopian Calendar } \\ \text { CUD } & \text { Coalition for Unity and Democracy Party } \\ \text { UDJP } & \text { Unity for Democracy and Justice Party } \\ \text { MPs } & \text { Members of Parliament }\end{array}$

Minorities Right to Political Participation under the FDRE Constitution: Saving the Plights of Ethnic Minorities in a Multiethnic City (Hawassa)

\section{Part I}

\subsection{Conceptualization of Political Participation in General: With Some Points in Reference to Minorities}

\subsubsection{Conceptualization of the Right to Political Participation}

Though uncontestable as the basic ideology of liberal democracy that legitimate and democratic government shall open the avenue for broad political participation of citizens ${ }^{1}$; the dilemma is whether citizens should be entitled to echo their interest within the institutional frame works provided for political participation, for instance, by voting and joining political parties, or whether it should be allowed in cases on when the participants deployed other means like, for instance illicit menses like riots and burning parliament building as long as it is conceived out of grievances, rages and dissatisfactions.

There are two theories responsive to the above question. In this respect, the theological perspective, which is derived from the Greek word telos, views political participation as a set of activities whose aim is to influence political authority; therefore, from the angle of this theory, as long as the political behavior is goal oriented its aggressiveness or violence does not count, ${ }^{2}$ thereby legalizing any kind of political engagement as afar as the movement articulates goals. Opposite to this, the procedural engagement (accords emphasis to the manner of participation) where it underlines that the rightness

\footnotetext{
${ }^{1}$ Lasonas Lamprianou, 'Contemporary Political Participation Research: A Critical Assessment', in K.N. Demetriou (ed.), Democracy in Transition: Political Participation in the European Union, Heidelberg, New York , 2013, Retrieved on March, 15/2015, Available at www.springer.com/cda/content/.../cda.../9783642300677-c1.pdf?.2013, $<$ www.springer.com/cda/content/.../cda.../9783642300677-c1.pdf?.2013, > p.22

${ }^{2}$ Id., p.23
} 


\section{International Journal of Education and Social Science Research}

ISSN 2581-5148

Vol. 3, No. 02; 2020

of political participation or engagement hinges on whether the manner of participation falls within the legal framework reserved for political participation of citizens ${ }^{3}$ in a given political polity or not.

The procedural engagement is well elucidated by Riley, who pointed out this; political engagement shall be held within "a set of rights and duties that involve formally organized civic and political activities (e.g., voting or joining a political party)", ${ }^{4}$ in line with this the recent protest in England was gauged accordingly (August 2011); for instance, Ed Miliband (the then opposition Labour Party leader) elegantly put it as follow as "the act ( he is referring to riots by students in contesting austerity measures ) constitutes violence even though students have reason to be aggressive; in similar vein David Cameron labelled the act (the then Prime Minister of England ) as acts of "pure criminality." 5

In lieu of the above contestations concerning the scope of the right to for political participation, it is prudent to wind up the matter via pointing of the definition aired out by Lasonas; for him political participation is a political engagement channelled under the "pre-specified" institutional norms designed for such aims irrespective of goals designed. ${ }^{6}$ In line with this, Jasiewicz reiterate that the right should also be made available to ethnic minorities as long as they express their political discourses and claims within the conventional forms of action. ${ }^{7}$

\subsection{Why for Minority Participation}

\subsubsection{The Need to Empower Minorities}

Empowerment being defined us to make (someone) stronger and more confident, especially in controlling their life and claiming their rights can be achieved through inclusion of minorities in political participation because participation is an outlet to that end. Participation permits minorities to demand 'minority positive rights' from the duty bearers that hasten the march towards empowerment. Minority positive rights is being defined in this contexts denotes the positive rights to minority education, to preservation of identity and culture, to participation and to self-government. ${ }^{8}$ Stated in simply language minorities' participation in the political institutions of the majority may force the latter to be sensitive concerning the implications of its decision upon on minorities.

\subsubsection{Democratic Stability Argument}

In country with democratic political institutions, the political involvement of their populations offers the opportunity to 'learn' about citizens' needs and preferences in order to improve government performance; in turn this inclusion into the polity also leads to higher levels of

\footnotetext{
${ }^{3}$ Id.,p. 24

${ }^{4}$ Id., p.22

${ }^{5}$ P., 23

6 Id., p.22-23

${ }^{7}$ Id., p.23

8 Tove H. Malloy, 'National Minorities between Protection and Empowerment: Towards a Theory of Empowerment', Journal on Ethnopolitics and Minority Issues in Europe, Vol. 13, No 2, 2014, p.21
} 


\section{International Journal of Education and Social Science Research}

ISSN 2581-5148

Vol. 3, No. 02; 2020

satisfaction, trust and regime support, contributing to stability. When groups succeeded through political participation to influence the outcome of decision-making processes and understand in the process that their views are valued in society is held to enhance feelings of belonging and identification of citizens with the larger community. ${ }^{9}$

\subsubsection{Enabler for the Exercise of Other Rights}

The nexus between participation and the assertion of their rights is eloquently elucidated by Florian Beiber ".. other rights and prevention of discrimination of minorities cannot be effectively ensured, unless the minority itself is actively partaking in the political decision-making processes which govern the protection of minority rights. Thus, without participation other mechanisms of minority rights protection can be substantially weakened... "10

\subsection{Barriers to Minorities Political Participation}

\subsubsection{Language Requirement}

In due cognizance of the ramification choice of working language bears on the right to stand for election by candidates from minorities group in a political atmosphere dominated by the majorities the human rights committee made its stance clear. The committee noted that any limitation or restriction on the right to elect or be elected in elections is justifiable only by exceptional circumstances or according to accepted principle. ${ }^{11}$ In this regard the work of the human rights committee provides a good deal of guidance on the limits of reasonable restrictions. The committee noted, inter alia, limitations on voting rights based on Language requirements are not falls out of reasonable zone of restrictions. ${ }^{12}$ Candidates should not be prevented from standing in election because they do not have the required language skills of the official or working languages of the national parliament. It is for the electorate to determine their choice of representative. ${ }^{13}$

\subsubsection{Minority unfriendly Election Laws}

Owning to misperceived view of minority parties as a threatening force to the stability of the state they have been under explicit or implicit restriction in partaking in elections by ethnic majority in power. The restrictions to the minority parties may take the form of a) bans and other restrictive

\footnotetext{
${ }^{9}$ Ada-Charlotte Regelmann, 'Introduction - Minority Participation in Estonia and Latvia' ,Journal on Ethnopolitics and Minority Issues in Europe, Vol. 13, No 1, 2014, p.1

${ }^{10}$ Florian Bieber, Balancing Political Participation and Minority Rights: The Experience of the former Yugoslavia, European Centre For Minority Issues, 2002/2003, Retrieved March,30/2014, Available at http://pdc.ceu.hu/archive/00001819/01/Bieber> ,p.1

${ }^{11}$ Guy S. Good win - Gill, 'Free and Fair Elections, Inter-Parliamentary Union', Geneva, 2006, Retrieved on March 30/2015 Available at <http://www.ipu.org/pdf/publications/free\&fair06-e.pdf> p.7

12 Human Rights and Election, a Handbook on the Legal, Technical and Human Rights Aspects of Election', Professional Training Series No.2, United Nation, New York, 2001, Retrieved on March `18/2014,Available at < <http://www.ohchr.org/Documents/Publications/training2en.pdf >,p.11

${ }^{13}$ Steven Wheatley,Non-Discrimination and Equality in the Right of Political Participation for Minorities, Journal of Ethnopolitics and Minority Issues in Europe ,Issue 3/2002, P.7

Supra note 11, p.7
} 


\section{International Journal of Education and Social Science Research}

ISSN 2581-5148

Vol. 3, No. 02; 2020

measures directed against minority parties; b) and c) inculcation of higher electoral thresholds. ${ }^{14}$ In touch with this the Venice Commission noted, general rules may promote or hinder representation of minorities. In any case the committee affirmed that bans on ethnic based political parties are ineffective, unusual and incompatible with human rights standards. ${ }^{15}$

Despite the cry of the international community for the deployment of all inclusive electoral systems, electoral gerrymandering (carving new electoral constituency to relegate the unflavored majority group into minority) $;{ }^{16}$ similarly, requiring higher number of signature for minority to get registered for election though known that the minority based party cannot meet requirement because lessor number of minority lives in that territory ${ }^{17}$. The other hurdle hampering minority participation is the case of high electoral threshold requirement. This requirement stifled parties representing the smallest minority group from accessing the parliament because often the parties failed to secure the necessary percentage of votes casted in the election, or speaking technically because they scored below the thresholds. ${ }^{18}$

\section{Part II}

\section{Democracy, Minorities and International Law}

Unlike the traditional conception of self-determination, which was the bedrock in the struggle from the yoke of colonization; the understanding this days recognizes self-determination is a right of peoples, not a right of States or governments. Therefore the conception is inward looking. Accordingly, self-determination presuppose peoples involvement in paving freely the country road map as far as economic, social and cultural development aspects are concerned. This right of the peoples is stressed under Article 1 of the two UN International Covenants: 'All peoples have the right of self-determination'. ${ }^{19}$ In its General Comment on Article 25 of ICCPR, the Human Rights Committee made it clear that the cumulative reading of articles envisaged the right to political participation of individuals as citizens of a nation without distinction to ' race, color, sex, language, religion, political or other opinion, national or social origin, property, birth or other status. So, individual's right to engage in the public affairs is aright warranted under international law. ${ }^{20}$

\footnotetext{
${ }^{14}$ Florian Bieber, 'Introduction, in Political Parties and Minority Participation", Friedrich Ebert Stiftung, Skopje, 2008, p.20,Retreieved on March 16/2015,Availabel at 


\section{International Journal of Education and Social Science Research}

ISSN 2581-5148

Vol. 3, No. 02; 2020

\subsection{The Rights to Political Participation of Minorities under the UN and European System}

\subsubsection{The Political Participation of Minorities in the UN System: The Right to Political Equality under the UDHR and ICCPR}

The States duty to involve citizens in the exercise of public affairs under articles 2, $25(1,2)$ and 21 $(1,3)$, of the ICCPR and UDHR respectively extends to the non-discrimination requirements. Therefore, this opens the avenue for persons belong to the minority groups the right to equal participation in the business of public affairs.

The Human Rights Committees non-discrimination approach to minorities political participation however, is short of group differentiated rights because the states except in case of (policy ) decisions that affects the identity of the minorities does not bear the duty to involve persons belong to the minorities in that process. The obligation of the states in this regard beyond assuring the inclusion of minorities in the decision that affects them through consultation procedures only extends to the duty not impede minorities endeavor to partake in the matters of general concern to the state in equal footing with persons belong to the majority. According to Kymlicka this Bill of Rights only goes half away to protect minorities because their share in the legislature is minimal, hence, he calls for special group representation so as to create representative legislature irrespective of population size. $^{21}$

\subsubsection{The UN Declaration on the Rights of Persons Belonging to National or Ethnic, Linguistic or} Religious Minorities (UNDM)

The declaration affirms for persons belonging to minorities to partake in cultural, religious, social, economic and public life' (Article 2(2)). The same document also notifies states to ensure the right to 'effectively participate in decision making forums both at national and regional level. The relevancy of the document cannot be downgraded due to the fact that its adaption was willed at the consensus of members of the UN General Assembly. ${ }^{22}$

\subsection{The Rights to Political Participation of Minorities under the European System: The European Convention on Human Rights}

Minorities' right to political participation is also well stressed under the Council of the European System. The provisions of the European Convention on Human Rights protect minorities in two

\footnotetext{
${ }^{21}$ In pursuance to Kymlicka there are three types of group differentiated rights that are helpful to shield minorities from the mighty will of the majority in multiethnic society. These reefers to special group representation, self-government and polyethnic rights; see Will Kymlicka, Multicultural Citizenship: A liberal Theory of Minority Rights, 1st edn. Clarendon Press. Oxford, 1995, p.37-38

${ }^{22}$ Tatjana Petrusevska,( ed.)'A guide to Minorities and Political Participation in South-East Europe', A Compilation of Conference Papers Presented at a Regional Conference held in Skopje on 10-11 March 2008, Common Values and the King Baudouin Foundation, 2009, Retrieved on March,19/2015, Available at Publications/PUB_1854 MinoritiesPoliticalParticipationSEE.pdft,p.22
} 


\section{International Journal of Education and Social Science Research}

ISSN 2581-5148

Vol. 3, No. 02; 2020

ways. It prohibits from the outset discrimination and promotes the right to identity. ${ }^{23}$ The European Convention on Human Rights and Fundamental Freedoms (ECHR) espouses articles harboring significance to minorities' right to political engagement. The chief among them is the right to freedom of expression supposed to be exercised without exclusion based on once own ethnic background. As safeguarded under article to the right is much helpful for minorities to articulate their demands. This right is supplanted by the right to freedom of assembly as safeguarded under article 11 whether it is on individual basis or in association with others as affirmed under art. $12 .{ }^{24}$ With the view to fortify the protection afforded to group right a number of additional protocols were in placed in particular bearing significance for the protection of ethnic minorities. ${ }^{25}$

\subsubsection{The Framework Convention on the Right of National Minorities}

Albeit briefly central to minorities' political participation is article 15 . The stipulation provides the right of persons belonging to national minorities to participate effectively in public affairs, in particular those affecting them. ${ }^{26}$ The FCNM obliges the state parties to create conducive environment for the realization of effective participation of persons belong to the national minorities. ${ }^{27}$ In line with Article 15, minorities have the right to participate in the decision-making process, at least on a consultative level. Thus, ethnic minorities would be entitled to institutional representation with offices and government structures, whereby their leaders are actively involved in the decision-making process. $^{28}$

\subsubsection{The Copenhagen Document}

In the Copenhagen Document, the participating States of the Organization for Security and Cooperation in Europe made decisive measures for the protection of the right to identity of minorities, which supersede in fact the afore said convention. The Document asserted that one way to protect the identity of minorities is to create 'appropriate local or autonomous administrations'. ${ }^{29}$ This proposed autonomy is understood to be significant for minorities to choose their governments and participate on those institutions decision-making process. ${ }^{30}$

\subsubsection{The Lund Recommendation}

The OSCE made its commitments clear via the adoption of the 'Lund Recommendations' on 'Effective Participation of National Minorities in Public Life'. This Recommendation 1 provides that 'in order to promote [political] participation, governments often need to establish specific

\footnotetext{
${ }^{23}$ Danova Militsa Danielova, 'Roma as Unique Cultural Minority: the Impact of Communism and Democratization on Roma in Eastern Europe', Durham theses, Durham University, Retrieved March 18/2014, 2011 Available at $<$ http://etheses.dur.ac.uk/875/>,p. 65

24 Id., p.64

25 Id. ,p. 65

${ }^{26}$ Supra note 22, p.22

27 Id.,p. 23

${ }^{28}$ Supra note 23, p. 67

${ }^{29}$ Supra note 23,p.63

${ }^{30}$ Id.,p. 67
} 


\section{International Journal of Education and Social Science Research}

ISSN 2581-5148

Vol. 3, No. 02; 2020

arrangements for national minorities'. ${ }^{31}$ Those arrangements under the recommendations among others encompass special representation of national minorities in the legislative process, formal or informal allocation of cabinet positions, seats on the supreme or constitutional court or lower courts, and positions on nominated advisory bodies or other high-level organs, special measures for minority participation in the civil service so that minorities can effectively echo their voices at the level of the central, regional and local level. ${ }^{32}$ The recommendation, on the other prong, for effective participation of minority calls for non-territorial or territorial arrangements of self-governance or a combination thereof. Moreover, the recommendation also foresees the need for the arrangement of non-territorial or territorial form of self-governance bearing in mind the call for effective minority political participation. ${ }^{33}$

\subsection{Minority Inclusion under Different Models of democracy}

\subsubsection{Political Participation of Minorities under Procedural Democracy}

Democracy, according to the Universal Declaration on Democracy, requires the existence of a parliament in which 'all components of society are represented...'or it should mirror the plurality of identity exhibited in the nation. It is important, for the reasons of legitimacy that the legislature reflects what the Canadian Supreme Court has called, 'the diversity of [the] social mosaic'. ${ }^{34}$

In order to remedy the past exclusion policy a number of policy options are tabled to the authorities. The State may, among this, amend the electoral system to ensure that the representation of persons from minority groups is maximized. ${ }^{35}$

\subsubsection{Political Participation Mechanisms for Minorities}

\subsubsection{Adequately Devised Election System}

There is an emerging consensus that for special distributed minorities the introduction of relative pure systems of proportional representation, where the percentage of seats in the legislature is roughly equivalent to the percentage of votes received will facilitate greater representation. ${ }^{36}$ Conventional wisdom in much of the academic discussions on minority representation suggests that proportional systems tend to be superior to majoritarian systems. ${ }^{37}$ As per Kymlicka electoral

\footnotetext{
${ }^{31}$ Supra note 19, p.141

32 OSCE High Commissioner on National Minorities, 'The Lund Recommendations on the Effective Participation of National Minorities in Public Life \& Explanatory Note', September 1999, retrieved on March 19/2014 Available at http://www.osce.org/hcnm/: see Part II, Para. 6-10, it recalls that effective political participation of minorities demand representation of minorities at the institutions of the central government while at the same remind us that electoral regulations should be tailored on the way that enables the achievement of effective political participation of persons belong to the minorities.

${ }^{33}$ Id., Part III Para. 14-21 of the Recommendation also calls for territorial and non-territorial arrangements in order to respond more effectively to the concerns of these minorities.

${ }^{34}$ Supra note 19, p.141

35 Supra note 19, p.144

${ }^{36}$ Ibid

${ }^{37}$ Supra note 14 , p. 17
} 


\section{International Journal of Education and Social Science Research}

ISSN 2581-5148

Vol. 3, No. 02; 2020

gerrymandering ${ }^{38}$ is also one valve for ensure minority representation because the states fabricates new majority constituency out of previous constituency were minorities were under dogs. ${ }^{39}$

\subsubsection{Representation by Quota}

Reserved seats for minorities tend to have one of two goals: protection or power-sharing. ${ }^{40}$ Reserved seats primarily seek to secure representation of smaller minorities which would not be able to achieve representation without such special measures. ${ }^{41}$ In the instances of protection by quotas, the aim is often to compensate for past oppression ${ }^{42}$. The introduction of Affirmative action has largely benefited smaller parties entrance into the political process because under the normal circumstances owing to their small size, they could not pass hurdles of high threshold or at times, high registration requirements for elections or party registration requirements stipulated under election laws of the concerned countries.

\subsubsection{Political Parties and Minority Participation}

Through political parties, minorities can achieve representation in parliaments and government. In a polity divided by ethnicity one may find parties taking different shapes, but it is not uncommon to find Monoethnic parties that generally appeal only to one community. Their program, membership and voters, thus largely hail from only one group, be it the majority or minority. ${ }^{43}$ Monoethnic parties appealing to the minority ethnic groups are found to be very attractive to these communities because of the fact that majority based parties gives deaf hear to the concern of minorities. This seems to continue in the long run as long the as the cleavages between the two groups persist. ${ }^{44}$

\subsubsection{Informal Channels of Participation: the Case of Advisory Bodies}

It is emerging practice that governments in still advisory bodies within the inner circle of their administration with the view to hear the voices of minorities; this serves as an avenue for minority sensitive political parties to be visible before the eyes of minority communities as active political actors. The Representation should not be for window dressing rather members are required to be directly elected by the concerned minority groups and assert claims of the group. ${ }^{45}$ The participation

\footnotetext{
${ }^{38}$ It is noteworthy to mention the fact that gerrymandering was historically deployed by white racist politicians in the Southern part of USA with the view to relegate black dominated constituencies into minority position. The current surge of redistricting are aimed to ensure that constituency really mirror the fact underground with view to ensure commensurate of representation blacks in USA, see Kymlicka Multicultural Citizenship: A liberal Theory of Minority Rights, 1st edn. Clarendon Press. Oxford, 1995, p.37-38,p.135

${ }^{39}$ Id, p.136

40 Mona Lena Krook and Diana Z. O'Brien, 'The Politics of Group Representation Quotas for Women and Minorities Worldwide', April 2010,Retrivied March 17/2015, Available at < www.mlkrook.org/pdf/krook_obrien_10.pdf> ,p.262263,

${ }^{41}$ Supra note 19,p. 24

42 Lena Krook and Z. O'Brien, Supra note 68,p.263

${ }^{43}$ Supra note 14 , p. 14

${ }^{44}$ Supra note 19, p.161

45 Dres. h.c. J.A. Frowein and Roland Bank 'the Participation of Minorities in Decision-Making Processes', Expert study on Issues Relating to the Protection of National Minorities, Max-Planck-Institute for Comparative Public Law and International Law, Heidelberg, November 2000, Retrieved on March 17/2015, Available at
} 


\section{International Journal of Education and Social Science Research}

ISSN 2581-5148

Vol. 3, No. 02; 2020

may take variety of forms inter alia includes establishing formal advisory or consultative bodies. ${ }^{46}$ Task wise such bodies usually comprise recommending measures for solving minority problems or commenting on government bills impinging on the position of minorities' ${ }^{47}$

\subsection{Moving beyond the Frontiers of Procedural Democracy: the road to hasten minority inclusive government}

In a procedural democracy, the majority/dominant ethno-cultural group will dictate the relevant convention. The fact is procedural inclusion is unlikely to alter the outcomes of decision-making processes though this aspects of democracy may deploy different channels for minority to air out their voices as hinted here. In deeply divided polity Political parties representing the majority govern permanently in the interests of the majority. Hence, this remained us for institutional rearrangements, which is portrayed traditionally in the image of the procedural democracy so that ultimately minorities can partake and equally influence decisions in the house of majorities. Therefore, the road responsive to this type of arrangement lays in the introduction of consociational pro type of democracy. The reason for this lays on the account of its schemes in brining minorities to the decision making platform via power sharing by all significant groups within the polity. ${ }^{48}$ Power sharing distributes rights to make decisions among ethnic groups of a nation.

\subsubsection{Consociational Democracy}

There are four central features in a consociational democracy namely, a grand coalition (or powersharing executive), proportionality in public life, a minority veto and segmental autonomy.

\subsubsection{Proportionality in public life}

Proportionality in public life has two aspects: the proportionate allocation of public goods, including public funding and employment in the public or State sectors, and proportionality in political representation. Proportionality in public life has two aspects: the proportionate allocation of public goods, including public funding and employment in the public or State sectors, and proportionality in political representation. The right of access to employment in the public sector is protected by Article 25 of the International Covenant on Civil and Political Rights without distinction based on irrelevant grounds. ${ }^{49}$ Related to this in deeply divided society , at the apex of the decision making ladder a state constitution may requires the composition of the executive cabinet from different ethnic, linguistic or religious groups, thereby avoiding incidence of homogenous executive, which is the case in instance where procedural democracy is instilled. ${ }^{50}$ Corollary to this, with the view to facilitate power sharing at the executive, electoral scheme preferred in consociational democracies is proportional system. ${ }^{51}$

<https://www.coe.int/t/dghl/monitoring/minorities/6_resources/PDF_DHMIN\%282000\%291.pdf>, P.16

${ }^{46}$ Supra note 19, p.157

47 Supra note 45, p.16

${ }^{48}$ Supra note 19, p.162-163

${ }^{49}$ Supra note 19, p.167

${ }^{50}$ Arend Lijphart , Thinking about Democracy: Power Sharing and Majority Rule in Theory and Practice, 1st edn., Routledge, Madison Avenue, New York, 2008,p,145, referee also in the same author p.167

${ }^{51}$ Id., p.48 


\section{International Journal of Education and Social Science Research}

ISSN 2581-5148

Vol. 3, No. 02; 2020

\subsubsection{Cultural Self-government}

Non-territorial autonomy is distinctively consociational. Under non-territorial, also known as personal or group, autonomy, members of communities may exercise their community rights wherever they reside or work in a state or region Such kind of self-government empowers minority' to partaking in decisions exclusively concern them. ${ }^{52}$

\subsubsection{Pluralist Federations}

Federations are best suited for sharing power schemes where there are deep national, ethnic and other cultural divisions. It recognizes more than one nation or people. This arrangement is a decentralized one: member-states wield significant decision making power in a single polity divided by different regions. ${ }^{53}$ Territorial self-governance rights stretches to participation at the national policy making arenas for ethno-cultural minorities. ${ }^{54}$

\subsection{Political participation under the Consociationalist Design: Macedonian Municipalities as an example}

Known a day's Power sharing via consociationalist approach is hailed is as the best institutional safeguards for group inclusion and participation. ${ }^{55}$ As Florian Beiber eloquently put it : power sharing is a credible tool in the interethnic accommodation and enshrines minority rights and political representation. ${ }^{56}$ To substantiate this assertions different mentioning a few examples suffices of course, albeit briefly; for instance, among other schemes, in Kosovo, by law, minority communities are guaranteed equitable representation in all public bodies and enterprises. As a consequence, recruitment procedures require public bodies to encourage the inclusion of minority communities. ${ }^{57}$

When it comes to representation of minorities, the 2003 Bosnia and Herzegovinian Law on Minorities stipulates that persons belonging to minorities "have the right to be represented in state institutions and public service at all levels in accordance with their share in population based. ${ }^{58}$

Turning ones attention to the diversity accommodation plan in Macedonia, which is, of course, the prime model this piece of paper suggests for Hawasa city to emulate in any endvour to accommodate

\footnotetext{
52 'Brenden O'Leary, the Logics of Power Sharing Consociation and Pluralist Federations' in Marc Weller and Barbara, Metzgerress (ed.), Settling Self-determination Disputes: Complex Power-sharing in Theory and Practice, Martinus Nighoff, Leidan./Boston, 2008,Retrieved on March 18/2015,Available at < http://www.brill.com/settling-selfdetermination-disputes, >,p.56

53 Id, p. 58

${ }^{54}$ Steven Wheatley, Non-Discrimination and Equality in the Right of Political Participation for Minorities, Journal on Ethnopolitics and Minority Issues in Europe, Issue 3/2002, p.10

${ }^{55}$ Florian Bieber, 'Power Sharing and Democracy in Southeast Europe', Taiwan Journal of Democracy, 2013,p.133

${ }^{56}$ Supra note 55, p.129-130

57 Id., p.138

58 Edin Hodžić 'Political Participation of National Minorities in Local Governance in Bosnia and Herzegovina: State of the Art, Prospects and Ways Forward', Analitika - Center for Social Research, Sarajevo, 2011, Retrieved March on 19/2015, www.analitika.ba , p.24
} 


\section{International Journal of Education and Social Science Research}

ISSN 2581-5148

Vol. 3, No. 02; 2020

the diversity prevailed in the metropolitan city, is rooted in the Basic Principles. The spirit of the later is underlined in the Framework Agreement that gives forgone conclusion that the local selfgovernments is essential for citizens engagement in public life and enhancing respect for the identity of communities. ${ }^{59}$ For this aim, the agreement ingrained non-ethnical municipalities, where no ethnic group is entailed to own municipal institutions. Any ethnic minority, whose population size comprise at least $20 \%$ in a particular municipality is espoused the right to receive public services in its language. The power of the municipalities cannot be seen lightly in lieu of the fact that they enjoy a constitutionally affirmed power in decentralization schemes. This power decentralization is made more meaningful with the introduction of consociational principle of proportionality requirement within municipal administrations, councils and committees. ${ }^{60}$

Minorities, whose population size is less than 20 percent, can claim the right to use their language as official one based, of course, the assent of the local authority (Constitution of the Republic of Macedonia: Art. 6.6). Art. 7 regulate the use of community emblems, such as the flying of community flags in front of local public buildings if that community constitutes a majority within a municipality (the Frame work agreement). All this measures are made more robust through the consociational principle that requires special voting procedures, (i.e. "double-majority" voting), envisaged to ensure greater consensus in decision-making within municipal councils, which is supposed to be exercised only in certain municipal acts. ${ }^{61}$

\section{Part III}

\section{Differentiating Minority from Indigenous Groups}

\subsection{A Glimpse View on the Concept as well as the Rights of Indigenous Groups under International Law and Minorities respectively}

\subsubsection{Defining the Respective Concepts: who are indigenous peoples?}

Definition wise, the term indigenous people has lend itself for variety of meaning on account of different contexts this group of people found and the suing endvour to offer protection that fits a given context. Making matters worse the United Nations Declaration on the Rights of Indigenous Peoples includes neither a definition of indigenous peoples nor even a provision that would specify the scope of application of the instrument. This doesn't imply that merely for that reason, we need to give up the endeavor to comprehend the conceptual points underpinning the legal meaning of the term indigenous. This doesn't mean that we are totally left without any clue. The prembular statement of this declaration hints a clue concerning group of persons, who can benefits from the

\footnotetext{
${ }^{59}$ Aisling Lyon, 'Between the Integration and Accommodation of Ethnic Difference: Decentralization in the Republic of Macedonia', Journal on Ethnopolitics and Minority Issues in Europe

Vol. 11, No. 3, 2012,p.89

60 Id., p.90-91

61 Id,p.92
} 


\section{International Journal of Education and Social Science Research}

ISSN 2581-5148

Vol. 3, No. 02; 2020

document or in short it implies the basic elements should any group of persons displays in order to enjoy the fruits of the declaration ${ }^{62}$; here in below are this Characteristics:-

1. 'Distinctiveness, in the sense of being different and wanting to be different.

2. 'Dispossession of lands, territories and resources, through colonization or other comparable events in the past, causing today a denial of human rights or other forms of injustice.

3. 'Lands (located in a specific geographic area) as a central element in the history, identity and culture of the group, usually giving rise to traditional economic activities that depend on the natural resources specific to the area in question. ${ }^{96}$

Amide the controversy whether the indigenous peoples should enjoy external self-determination ${ }^{64}$ through considering them as people (i.e. as per the spirit of article 1 of ICCPR and ICESC peoples are privileged to claim the external aspects of self-determination even in the instance where colonization is ended $)^{65}$, the United Nations Declaration on the Rights of Indigenous Peoples comes with compromising approach. A per this document indigenous peoples can qualify for selfdetermination rights without compromising territorial integrity and right to self-determination of indigenous peoples. This, they freely determine their political status and freely pursue their economic, social and cultural development. ${ }^{66}$

\subsubsection{Who can be accounted for the definition of Minorities?}

It is prudent to define minorities before jumping to clarify the difference between minority and indigenous groups. Though the word minority has been mentioned several times in the international legal instruments, we still luck a workable definition for minorities capable of commanding general approval. Indeed, this should not be utilized to deny protection for groups, who sought protection because of their vulnerability.

Amide this definitional controversy the definition hinted by UN Special Rapporteur Capotorti is much helpful. He proposed that minorities are 'A group numerically inferior to the rest of the population of a State, and in a non-dominant position, whose members - being nationals of the State - possess ethnic, religious or linguistic characteristics differing from those of the rest of the population and show, if only implicitly, a sense of solidarity, directed towards preserving their culture, traditions, religions and language ${ }^{67}$ Capotorti's definition among others is not responsive to the question whether those ethnic groups who possess small size of population, but wields substantial

\footnotetext{
62 Minorities, Peoples and Self-Determination Essays in Honour of Patrick Thornberry, Nazila Ghanea and Alexandra Xanthaki ( edi. ), Martinus Nijhoff Publishers, P.3-4

63 Id., p.3-4

${ }^{64}$ Yichao CHEN, The Rights to Self-Determination of the Indigenous Peoples - Illustrated by Arctic Indigenous Peoples, Master"s Program in Polar Law, 2010, p.2,

65 Id, p. 6

${ }^{66}$ Id,p.4-5

${ }^{67}$ Samia Slimane, Recognizing Minorities in Africa, Minority Group International P.1-2
} 


\section{International Journal of Education and Social Science Research}

ISSN 2581-5148

Vol. 3, No. 02; 2020

power of the states can be audited in the definition for minority. Owning to this pitfall of the definition a refinement is proposed Jules Deschênes in 1985. The definition albeit briefly, stress that a group of people may constitutes numerically inferiority (i.e. they may be in non-dominant position), but appears to be at the climax of power distribution, therefore, the touchstone whether a group could qualify for minority rights protection is the amount of public power it commands. ${ }^{68}$ Therefore, in the lieu of this proposal the Harare ethnic group cannot claim the protection in the status of minorities as currently the regional state constitution reserves significant power to the group. The reverse may not deter a group from enjoying minority protection schemes though numerical they may be in dominant position. ${ }^{69}$

\subsubsection{Hammering on the Difference between the two Groups under International Law}

Labor and time has been consumed before the international instruments and states practices pointed out a clear distinction between minority and indigenous groups. But, now this is not the case. Despite the wrangling debates on their difference, there is a consensus that immaterial of the status of a group (whether it is minority or indigenous), the claim sought shall not pose threat to the territorial integrity of the host state.

A bit briefly the distinction between the two groups of people is in order here in after; one basic departure between the lays to the fact that Indigenous rights involve not only equal rights and nondiscrimination but also special measures extending, among other things, to possession of land and to benefits from natural resources. Autonomy or self-government, not least with reference to language on the management of land and resources in ILO Convention No. 69, sometimes referred to as internal self-determination, may also be more readily available to indigenous peoples than to minorities. 70

Unfortunate for minorities, the right to internal self-determination is not synonymous to them at best at present; international law does not accord internal self-determination rights for minorities. The rights of persons belonging to minorities differ from the rights of peoples to self-determination. The rights of persons belonging to minorities are individual rights, though as a matter of fact those rights cannot be effectively utilized without recognizing the collectivity aspects the rights themselves entail (i.e. in short they are supposed to be exercised in community with others ). The rights of peoples, on the other hand, are collective rights. While the right of peoples to self-determination is well established under international law, in particular by common article 1 of the ICCPR and ICESCR, it does not apply to persons belonging to minorities. ${ }^{71}$

\footnotetext{
68 P.2,

${ }^{69}$ Beza Desalegne, a PhD Desertion Submitted to Addis Abeba University, School of Graduate Studies, p.34

${ }^{70}$ Minorities, Peoples and Self-Determination Essays in Honour of Patrick Thornberry, Nazila Ghanea and Alexandra Xanthaki ( edi. ), Martinus Nijhoff Publishers, P. 68-69

${ }^{71}$ Supra note 64,p.9
} 


\section{International Journal of Education and Social Science Research}

ISSN 2581-5148

Vol. 3, No. 02; 2020

The right to internal self-determination for the indigenous peoples is justified on the account of the intimacy the group established with the land they inhabited. They have lived there from time immemorial or at least from before the arrival of later settlers. In addition, the indigenous ways of life much of the time also depend on or are closely interwoven with land, including the links of traditional economies to the land, such as for fishing, gathering, herding or hunting. ${ }^{72}$ It is obvious from this indigenous groups relish a bundle of rights that are not available for minorities; be this as it is, it would be wise after this, to expound the rights minority groups can seek form states and international law.

\subsubsection{The Rights of Minorities under International Law: what are the specific content the rights?}

Despites the endeavor's the international community is striving, still minorities are under the jackboots of the political elites of the majority. The projects designed and promises entered by states fail to match the expectations. The reason for this is a score the promises Part of the Giving cognizance to the fact that, even though, a number of minorities are found scattered around the globe they still face prosecution and torture. Even the western world gives deaf ear to the promotion and protection of the rights of minorities due to the ill-conceived belief that any endeavor on that road ends up in destabilizing the unity of the states. Recently, however, the international community witnessed surge of conventions meant to safeguard the rights of minorities.

The first of its kind is the ICCPR as binding international instrument aimed at the armoring the rights of minorities. Under article 27 provides shields to individuals belonging to ethnic, linguistic and religious minorities from any ill-conceived effort to curtail the individual exercise of rights by individuals because of their membership to the aforesaid groups, to the dismay of the group , however, the protection is not to minority group per se. In this regard, the draft instrument is generous enough in recognizing the rights of minority as group of people. ${ }^{73}$

To sum up article 27 bores its own limitations as noted in the following passage: [t]he Article finally adopted refers only to persons belonging to such minorities [ethnic, linguistic or religious]. The idea of collectivity, however, was not totally rejected, since Article 27 recognizes the rights mentioned may be enjoyed "in community with the other members of the group." Nevertheless, the concept of group rights, as such, faced stiff resistance because members of the UN feared such recognition may open a door for dismemberment from the host states. ${ }^{74}$

Adorning the efforts displayed so far it will not be mistaken to say that, the enjoyment of individual human rights for members of minority group would not be fully attained unless otherwise the state

\footnotetext{
72 Supra note 69, p.169

73 Belay Shibeshi Awoke, Minority Rights Protection In The Amhara National Regional State: The Case Of The Kemant People In North Gondar, P. 21

${ }^{74}$ Supra note 73, p. 21
} 


\section{International Journal of Education and Social Science Research}

ISSN 2581-5148

Vol. 3, No. 02; 2020

recognizes collective aspects of minority group rights in lieu of in particular past discrimination and disempowerment. Here, the collective rights to language can best serve to back up the assertion.

The non-exclusion approach for the enjoyment of human rights without supplanting it with group's rights has a birth defect; it treats equally those who are not actually equal. Members of the minority are not in equal footing with the members of the majority. There is a need to treat differently those belonging to the minority till they come near to equality with the members of the majority. Expressed in simple terms, for instance, the instrumental value of language if recognized as group right would serve best the individual right to freedom of expression in the diversified group's right if persons are entitled to communicate with each other via their language. The intrinsic value view's language by itself is a manifestation of the dignity of the individual and it is impossible to separate language from the group. Protection of the linguistic group is just protecting the dignity of the individuals belonging to such group. The official recognition of the language member of minority boosts the self-esteem of individuals from that sodality. ${ }^{75}$

\subsubsection{Specific Contents of Minority Rights under International Law:}

The concerns of minorities require sets of rights particularly designed to protect their interests. Though not exhaustive here are some of the rights that bore high significance for:-thus, this section, points out some of these rights.

A) Recognition (existence) "The linchpin of minorities ['] protection is the right of minorities to be recognized as minorities", which gives birth to struggle for other rights that had vitality for them. ${ }^{76}$

B) Language: language plays a vital role in either in empowering or disempowering a certain ethnic group as well as increases the self-esteem of those, whose language is the medium of instruction in school and choice as official language of the state. ${ }^{77}$

C) Culture: being as a component of ethnicity, the collective aspect of cultural life is protected under article 27 of the ICCPR as included in ethnic minority. A minority's interest will be promoted and protected by respecting the value of its cultures. ${ }^{78}$

D) The right to partake in the public affairs: as per the biding comments of the Human Rights Committee on article 25 of the ICCPR, people's rights for self-determination is to be construed in post colonization period to meant the requirement that governments shall ensure the participation of citizens without any biases on terms of for instance ethnicity in setting public policies. Therefore, these internal self-determination rights of the people by implications shall be inclusive of the partaking of minorities in designing of states policies.

The effective utilization of the rights enshrined under this convention nothing less than that is required; article 27 entitles persons belonging to religious, linguistic and cultural minority of

\footnotetext{
75 Ibid

76 Id,p. 27

77 Id,p. 28

$78 \mathrm{Ibid}$
} 


\section{International Journal of Education and Social Science Research}

ISSN 2581-5148

Vol. 3, No. 02; 2020

course together with others members of their own to claim the promotion and protection of their language, culture and religion. This right demands the inculcation of positive measures with the view to shield minorities from violation, which includes among other licensing minority representatives involvement in decision making arenas of the majorities

\subsubsection{Territorial Autonomy for Minorities?}

There is a wrangling debate on whether international law entities minorities territorial autonomy. There is opposing argument on the point, but the most dominant position restricts the application of the right either to the indigenous groups or peoples as whole making up the state. In cognizance of the merits of the argument forwarded in favor of conferring territorial autonomy here in below we will sum up the bedrock of their presentation albeit briefly.

The contenders insist that it is only peoples who can aster the right to self-determination espoused under arti. 1 of the ICCPR in exclusion of minorities because minorities luck precious elements peoples possess namely, land. Aureliu Critescu advocates for self-determination of "peoples"; he lays down that this term denotes a social entity possessing a clear identity and holds a relationship with a territory. ${ }^{79}$ But scholars seem hard pressed to articulate this differentiate as viscous rather they content that this type of distinction complicates protection schemes. Professor Ian Brownlie, for instance, has asserted that "the issues of self-determination, the treatment of minorities and the status of indigenous populations, are the same, and the segregation of topics is an impediment to fruitful work."'. He goes on to argue that the recognition of group rights, that is, minority rights, represents the practical and internal working of the concept of self-determination, between the concepts of selfdetermination and minority rights, providing a link ${ }^{80}$. Brownlie contends that the core of the principle of self-determination consists of the right of a community that has a distinct character to have this character reflected in the institutions under which it lives. ${ }^{81}$

Patrick Thornberry has argued that minority rights are really a form of human right because any system of human rights must recognize that people exist not simply as individuals, but within their cultural settings. Both individual rights and rights addressed to protecting minorities are necessary for the perpetuation of minority cultures and the protection of the human rights of the individual members of those cultures. Others have expressed the relationship. Thus, minorities need special rights to defend their cultures in order to give meaning to other fundamental human rights, such as equality between individual and group rights as follows: group rights are necessary to ensure the effective implementation of fundamental individual rights, because if minorities are not given rights specifically designed to defend their culture they will be treated unequally and unjustly. ${ }^{82}$ Without these "special rights" members of the minority possess only the right to assimilation into the

\footnotetext{
${ }^{79}$ Claudia Saladin, Self-Determination, Minority Rights, and Constitutional Accommodation: The Example of the Czech and Slovak Federal Republic, 1991, Michigan Journal of International Law, Volume 13/ Issue 1,p.175 80 id,p.176

${ }^{81}$ Id,p.176-177

82 Supra Note 82,p.178
} 


\section{International Journal of Education and Social Science Research}

ISSN 2581-5148

Vol. 3, No. 02; 2020

dominant culture. ${ }^{83}$ Hence, this approach refutes traditional assumption and the classical liberal ideology, which is known to insist in the formulation that the standard human rights (i.e. individual rights) if affirmed then group rights will automatically be protected. This assumption, however, does not address the claimed right of groups to take positive action to maintain their cultural and linguistic identity ${ }^{84}$ because owning to past discrimination the playing field is not level. ${ }^{85}$ The philosophy coined by the League of Nations PCIJ is instructive of the importance of the need to go beyond mere accord for the respect for individual rights without the schemes of positive measures as underlined in Minority Schools in Albania Case. Here the court stressed the fact that narrowing the gap between equality in law and fact is mandatory. In the words of the court: Equality in law precludes discrimination of any kind; whereas equality in fact may involve the necessity of different treatment in order to attain a result which establishes equilibrium between different situations ${ }^{86}$.

It is easy to imagine cases in which equality of treatment of the majority and of the minority, whose situation and requirements are different, would result in inequality in fact. . . . The equality between members of the majority and of the minority must be an effective, genuine equality.... ${ }^{87}$

The focus on the individual manifests itself at the domestic level in the concepts of equality and nondiscriminatory treatment. The principle of "one person, one vote," however, makes it highly probable that some people will be relegated to the status of permanent minorities, and so may serve discriminatory ends. The focus on group rights manifests itself at the international level by permitting particular groups to look after their own interests in relative independence from other groups. The problem in plural societies is how to combine these competing principles of individual rights and group rights in a manner that protects both. Although it would appear that group rights are necessary to protect individual rights, nevertheless a conflict is perceived between individual and group rights. ${ }^{88}$ This because entailing group rights for some section of the society for instance, indigenous groups in the form of self-determinations holds ramifications for the other inhabitant of the territory, who will be considered as alien and therefore, have no group rights ( i.e. minorities ).

In to the international documents pertinent to minority rights focus non-discrimination and equality clauses. For instance, article 27 of ICCPR stress on States tolerance and duty to refrain from interfering with their cultural or religious practices of minorities, in similar footing ICSCCR imposes obligations on states to permit minorities to partake cultural life, but not the right to use a language. 89 Therefore, as a way out for this quadrime, here the paper would like to be suggestive for the introduction of power sharing arrangement so as indigenous groups autonomy or self-government

${ }^{83}$ Id,p.178-179

${ }^{84} \mathrm{Id}, \mathrm{p} .178$

${ }^{85} \mathrm{Id}, \mathrm{p} .179$

${ }^{86}$ Id,p.181

87 Ibid

${ }^{88}$ Id,p.179

${ }^{89}$ Supra note $89, .185$ 


\section{International Journal of Education and Social Science Research}

ISSN 2581-5148

Vol. 3, No. 02; 2020

may co-exists with the promotion and respect for human rights of minorities living amide the regional empowered groups. This may be helpful for minorities to co-exist with the empowered group so as the scheme aid them in shielding their identity and languages from assimilation.

\section{Part IV}

\section{The Right to Political Participation under the FDRE Constitution: With Particular Reference to the Multiethnic Cities in Ethiopia}

In direct departure to the past as of 1991 Ethiopia has aspired to build democratic institutions that respects both individual and collective rights that is supposed to be achieved with the participation of citizens individually as well as collectively by nation, nationalities and people's, who are the holders of ultimate power in the country. ${ }^{90}$ Indeed in order to realize this objectives a dozen of constitutional stipulations are provided that are helpfully for individuals to partake in the conduct of public affairs; not only this but also in the words of Fasil 'this is not constitution of the Ethiopian citizens simply lumped together as a people",91 rather nations, nationalities and peoples are identified as separate unit with legitimate claim for self-rule for matters exclusively concern them, at same time enabling to them to have as a say at the center on matters of common interest.

Before dealing with stipulations provided for that end, however, defining, who are minorities in the Ethiopian context is relevant. Though internationally we lack uniformly accepted definition for minority, with all its defects Capotorti proposal could be used to give light on the matter. According to him the prime marker of minorities are being in non-dominant position and the intuition to aster once of own distinctive characteristics. Another definition forwarded by Jules Deschens adds another color to the basic touchstones to identify them namely, the motivation to maintain equality in law and fact per se. ${ }^{92}$

The FDRE constitution though silent concerning subjects, who can be accounted minorities; we can figure out work definition the term minorities. Therefore, here is the solution albeit briefly in summery formats: taking into account numerical size with no single ethnic group accounting for the half of the population, all ethnic groups deserve minority protection at federal level, whereas majority-minority relationships characterize most of the regions. In the five region named after the numerically dominant ethnic group there exist a group of scattered people's in the midst of them giving rise to majority and minority tension. Neither the rest regions namely SNNP, the state of

\footnotetext{
90 The Transitional Charter of 1991 under para. Three of the preamble foresaw the establishment of a democratic government by the people, who respects and safeguard the interest of the deprived citizens. In a similar vein Art.2 (b) vests an obligation for government institutions to be the reflections of the 'will of nations, nationalities and people's of Ethiopia

${ }^{91}$ Fasil Nahum, Constitution For Nation of Nations: The Ethiopian Prospect, $1^{\text {st }}$ edn., the Red Sea Press ,Inc. Princess Road, Lawrenceville, 1997 ,p.51

${ }^{92}$ Abera Degefa, The Scope of Rights of National Minorities under the Constitution of Federal Democratic Republic of Ethiopia, Series on Ethiopian Constitutional Law, Vol. 1, AAU Printing Press, Ababa University,2000,p.25-26
} 


\section{International Journal of Education and Social Science Research}

ISSN 2581-5148

Vol. 3, No. 02; 2020

Benishangul-Gumuz and the state of the Gambella peoples are immune from minority challenges because in these regions with no group constituting majority all ethnic groups bears the name minority. ${ }^{93}$ So this telling that a part from those, who deserves minority protection at the federal level, where the dominant once are in turn vested with their own regional states so as they may promote and protect their own identity, but amide them there are scattered minorities, who have their own regional states somewhere in the federation. The later instance gave birth to the phenomena of new form of regional minority after the demarcation of the regional states. The rights of these minorities groups as afar as in the collective aspects are concerned the international law remains at odds with their quest except the traditional equality clauses.

In lieu of the above philosophy, this paper identifies two categories of peoples as deserving minority protection schemes. Hence, albeit briefly, in the first category we can find those, who have been politically excluded and marginalized in the past due to the nation building project (who are mostly refers to us by the name indigenous group in the regional constitutions); whereas in the second category this paper proposes ethnic residents (non-indigenous groups), whose life is intermingled with the regionally empowered indigenous group ought to be regarded as minorities. The reason for later group lays due to exclusion they face from running to the regional parliament, and the denial of any avenue to reflect their identity in the regional public institutions (i.e. the exclusion comes due to the fact of non-belongingness to the titular groups empowered and termed as non-indigenous groups). ${ }^{94}$

\subsection{The Right to Equitable Representation under the FDRE Constitution (the Case of Collective Right)}

With reference to the collective rights for political participation, it is clearly affirmed under Art.39 (3) of the FDRE constitution to encompass the right to equitable representation in state and federal government. According to Assefa the collective rights for equitable representation runs beyond the shared rule aspects in the two federal houses, rather extends to the executive branch including the civil service and Judiciary ${ }^{95}$ hence, conferring the avenue for minorities to protect their interest at federal decision making arenas though, unsettled whether such equitable representation also extends to regional minorities. Based on the identification to be made by another law minority are assured the right to political participation (i.e. federal level, Art.54 (2) and (3) provides special representation to the small sized minorities in HoPR).

\footnotetext{
93 Id,p.35

${ }^{94}$ Yonatan Tesfaye and Christophe Vander Beken, 'Ethnic Federalism and Internal minorities: The Legal Protection of Internal minorities in Ethiopia' ,African Journal of International and Comparative Law, 21.1 (2013):, p.46

${ }^{95}$ Assefa, Federalism and the Accommodation of Diversity in Ethiopia: A Comparative Study, 1st edn., Nijmegen: Wolf Legal Publisher, 2006,p.28 ${ }^{95}$
} 


\section{International Journal of Education and Social Science Research}

ISSN 2581-5148

Vol. 3, No. 02; 2020

\subsection{Individual Rights under the FDRE Constitution}

As regard individual rights of citizens, the FDRE constitution has recognized many civil and political rights. ${ }^{96}$ The political right refers to the power of an individual to participate in choosing representatives and candidates with the view to run government offices. It also involves the freedom of expressing political opinion.

\subsection{Political Participation in the Case of Multi-ethnic Cities in Ethiopia}

The multi-ethnic nature of cities in Ethiopia necessitates the devise for co-decision making process with the view to facilitate ethnic group's quest for the promotion and protection of their, the FDRE constitution, however, despite of this quest lacks a clear legal standard that authorizes ethnic residents of a city to partake on co-decision making process. The mandate of this legal standard, however should make beneficiary the indigenous groups beyond for such desire for the ethnic residents. Such desire of the indigenous groups, in particular, is obligatory to be fulfilled with needless to mention because the cities are located in the peripheral limits of the so-called indigenous groups, though a few in number are clearly affirmed with the right to self-determination in article 47 of the FDRE constitution.

It is far from being clear, to be honest, on whether ethnic residents ( the so called non-indigenous groups) can absorb the fruits of self-determination rights as espoused under article 39 of the FDRE constitution and the bundle of rights the article carries. Tamerate Delelegne seems to be certain in this assertion concerning the status of cities. He contended for cities in the context of the FDRE constitution to falls short of the right to self-determination for the afore said groups, He goes on to explain that this describes the reason on why cities councils are deprived of legislating on identity matters. ${ }^{97}$ They only guarantee and enjoyment they can claim ,as the current practices suggest, the individual right to political participation through popularly elected councils in accordance laws made by the respective regional states as part of their residual power demonstrate. ${ }^{98}$

In order to tackle those problems exploring foreign experience is necessary in order so as Ethiopian city councils can respond positively to those conflicting demands. Hence, in this regard the Macedonian experience, more than any other country here in before, can be instructive. This is our cities can be conferred with the mandate to legislate on language and identity matters in general based on the prevailed contexts underground, rather letting the regional legislature to determine on all delicate and identity matters as the experience of Macedonia testifies. Macedonia is well known

\footnotetext{
${ }^{96}$ Chapter three of the FDRE Constitution

${ }^{97}$ Though city residents can be equated as peoples because they are collection of persons, but they cannot be assimilated to the type 'peoples' referred under Art.39, 52(2) and 88(1) because of failer to meet the qualification of 'peoples' under Art.39(5) due to the reason that they do not share the same history, language ,religion, identity, see the detail for this Tamerate, The core elements in the definition of Cities by various City laws in Ethiopia includes the community shall have a population of $\mathbf{2 0 0 0}$ or more, whose majority must engage in industrial, commercial or service activities, see the detail for this Tamerate Delelegne, 'The Legal Basis for Self-Rule in Ethiopian Cities', Journal of Ethiopian Law,Vol.26,No.1,2006, p.39,p.58-59

98 Supra note 98 , p.55
} 


\section{International Journal of Education and Social Science Research}

ISSN 2581-5148

Vol. 3, No. 02; 2020

for the fact of power decentralization on identity issues. For instance, Macedonian Municipalities are endowed with the power to legislate on identity matters. ${ }^{99}$ But, this doesn't mean that city councils remain without the control and accountability to the regional legislature. The advice is to let our city exercise law making power which confers contextualizing chances with the overall ridding power of the regional legislature as just like municipalities are accountable to in Macedonian to the central authority ${ }^{100}$ in a similar vein, it noteworthy to mention that cities in Ethiopia are accountable to regional government for the implementation of federal and regional laws. ${ }^{101}$

Other similar features can be exhibited in a way the Macedonian states structures designed and the political structures instilled in majority of the regional constitutions. This refers to the fact the accommodation design is not meant disempower the Macedonian community throughout the territories of the state ${ }^{102}$ rather the endvour is to respond to the other minority rights settled throughout the periphery of the state but seizing significant numbers in municipalities and harboring intuition to promote their identity in particular their language. So the lesson is when we contend the need to emulate the Macedonian design of accommodation at the city level in Ethiopia there is no desire on the part of the writer of this paper to disempower the regional dominant group (i.e. the indigenous group), but rather to positively react to the demands of those ethnic minorities, ${ }^{103}$ who are co-habiting with the empowered group in large size, but exhibiting different identity character to the indigenous. Therefore, easy to see this, if we are contemplating to adapt the Macedonian approach based on this paper recommendation, then we cannot be accused of disenchantment of the old policy of one language one nation because the proposed scheme is observant of the quest of the varies groups for the observance of their identity. This statement sums up the intention of the proposal "...the recognition of other ethnic communities language does not affirms a symbolic recognition of their equal status with the Macedonian language; rather the recognition comes as a function of demographics..." 104

Interims of implementing the above assertion we proposes this; here Macedonian experience dictate us to institutionalize proportionality schemes at municipal administrations, Councils and Committees, while reserving fairly balanced quotas to the indigenous groups, who owns the regional peripheral limits as per the words of some of the regional constitutions. In order to link participation with promotion and protection of identity, then the way forward is to rethink standard setting by the federal constitution that, for instance, authorize the usage of secondary language to whom ever meet

\footnotetext{
${ }^{99}$ Supra , note 59 ,p.90

100 Id., p. 89

${ }^{101}$ Supra note 98, p. 87

102 Supra note 59,p. 91

103 Those ethnic minorities (i.e. politically, but not numerically in particular in multi ethnic cities) who are not well versed in the working language of the regional states are largely excluded from running to elections for the Regional Councils, effectively curtailing the right to representation. Here in this regard the approach followed in the case of SNNPR is adorable as it reserve $70 \%$ to those, who belong to the non-nominal group ; see for the detail for this first Yonatan Tesfaye and Vander Beken, Supra note 95,p.46 and see also the detail in Tamerate ,Supra note 98,p. 72 ; 104 Supra note 59,p.91
} 


\section{International Journal of Education and Social Science Research}

ISSN 2581-5148

Vol. 3, No. 22; 2020

certain numerical thresholds (i.e. here the reference for the case of ethnic minorities or nonindigenous groups based on their numerical size). Moreover, introducing Consociationalist principles at city level without disempowering the indigenous group should is also be contemplated.

Solomon and Christophe eloquently put it; non-indigenous groups can claim the non-territorial aspects $^{105}$. Therefore, the constitution, for this aim, should work out on the detail how the rights affirmed under Art. 39 are to be exercised without any distinction between indigenous and nonindigenous groups can be exercised in multiethnic cities' institutions for the rights to be exercised on non-territorial basis. In sum the mandate remains on the FDRE constitution as part of its standard setting mandate to provide detail laws so as cities in Ethiopia can accommodate the right to equitable political participation and the right to promote once own language and culture to the ethnic residents ( non-indigenous groups ) proportionate to their numerical size, without disenfranchising the indigenous groups on similar matters due to the ethnic federalism the country is experimenting ( their self-determination rights). Therefore, the suggested federal standard cannot be held to demote the right to self-governance of the indigenous groups because the approach will not hamper the intuition of this peoples to promote their identity and language ${ }^{106}$ because the ethnic minorities will only enjoy from the introduction of second language, which will only work side by side with the working language of the indigenous society. They indigenous groups can still reflects their distinctive characteristics in the local institutions. ${ }^{107}$ Moreover, the power sharing scheme is concerned the ethnic minorities only will be espoused with restricted quota number for the participation in the city council and executives. Any approach beyond this will only confers untrammeled rights to the indigenous groups; so the conclusion is ethnic minorities should be entailed with a qualified form of collective rights. Here this statement support the balanced path followed by this paper: - Margaret Moore cogently challenges that the assumptions that indigeneity confers superior entitlement to land, the elucidation to this goes like this: the human migration is and has been extremely common: many people are descended from people who came from somewhere else, and it would be very difficult and problematic to assign (general) rights to people based on where their ancestors originated. Where people originated may not bear any relation to where or who they are now. Non-indigenous people may feel a strong attachment to the place where they were born and not to the place where their ancestors came from. An alternative approach would be to give some people rights based on where they originated (indigenous people), but diminished rights to those people whose ancestors at one

\footnotetext{
105 Christophe Van der Beken, 'Federalism, Local Government and Minority Protection in Ethiopia: Opportunities and Challenges', Journal of African Law, December 2014, p.12; see also Yonatan and Vander Beken, Supra note 95 , p.4143, see also, Solomon Emiru,' The Human Rights Commission and its Role in the Protection of Minority Rights: A comparative Study', an LLM Thesis Submitted to the Institutes of Federalism and Legal Studies ,Ethiopian Civil Service University, p.43

106 Margaret Moore ,'The Right of Indigenous Peoples to Collective Self-determination' Retrieved on May 31/2015, Available at < http://ecpr.eu/Filestore/PaperProposal/c6f67564-8402-444f-8e34-b76c31b1c3b2.pdf> , Helen O’Nions, Minority Protection in International Law: the Rome of Europe, $1^{\text {st }}$ ed. , p.6-7

107 Helen O'Nions, Minority Protection in International Law: the Rome of Europe,1st, Ashgate Publishing Limited, Hampshire, England, 2007, Retrieved on May ,29/2015, available at England http://www.ashgate.com, p.123 and 251
} 


\section{International Journal of Education and Social Science Research}

ISSN 2581-5148

Vol. 3, No. 02; 2020

time migrated. If we take the view that any principle or policy should be capable of being justified to the person or group who does worst under it, it is not at all clear that it is straightforward to justify an inferior right to people born in a place but descended from one line of people, whereas others, who are descended from a different line of people and who are therefore indigenous, may have a superior right. ${ }^{108}$

\section{Part V}

\section{The Right to Political Participation under the SNNP Constitution: the Case of Hawassa City Administration}

The Southern constitution unequivocally envisages a nation building project based on the protection and promotion of diversity that has already signaled in the preamble, which affirms the respect for both individual and group rights. In order to achieve this Art.39, which is regional copy of Art.39 the FDRE constitution, provides three important categories of minority rights protection devises : language rights and cultural rights, the right to representation in political institutions (in both regional / federal institutions) and the right to territorial autonomy. ${ }^{109}$

The regional constitution provides for regional legislative, judicial and executive bodies. Concerning the right to political participation in the regional institutions, in one of the regional parliamentary houses we see the differentiation of indigenous and non-indigenous groups. In the states' council, which is the highest legislative body in the region, there exists interesting scheme of minority inclusiveness. The constitution has foreseen the non-representation of numerically smaller minorities because of the plurality election system the country has adapted, hence provides guaranteed representation for 'national minorities and people's. ${ }^{110}$ So far in the first term of the Council there were nine members representing national minorities. ${ }^{111}$

Another regional institutional in the SNNP Regional State, which is unique to the region and modeled after the $\mathrm{HoF}$ in terms of the composition is the Nationality Council, whose power and composition are specifically tended to achieve regional unity in diversity. The constitutional direction on the composition of the council has resulted in achieving access to political participation for 56 ethnic groups that are represented by 61 members $^{112}$, whose election from the zones and

\footnotetext{
108 Margaret Moore, 'The Territorial Dimension of Self-Determination' in Margaret Moore ( ed. ), National Selfdetermination and Secession, 2nd, Oxford University Press , Great Clarendon Street, New York, United States, 2003, Retrieved on May 31/2015, Available at <http://ukcatalogue.oup.com/product/9780198293842.do,> , p.134 ${ }^{109}$ Christophe Van der Beken, Federalism in the Context of Extreme Ethnic Federalism: the Case of Ethiopia's Southern Nation and Nationalities and People's Region, Verfassung und Recht in ubersee ,2013, p.13 Id., P. 5-6

110 Supra note 111 ,p. 5-6

111 The information on the Special Representation for minorities received from the Information and Documentation Core Work Process of the Regional Council during an author interview with Ato Ayenekulu Gohastebah, Information Officer, April 15/4/2015, 3:20pm -4:30 pm (Local Time).In addition to this, the information on the nationality as well as Zonal /Special Woreda compositions of the Council in the Fourth Round, which has been annexed to this paper was obtained from this Center.

112 Supra note 111 , p. 14
} 


\section{International Journal of Education and Social Science Research}

ISSN 2581-5148

Vol. 3, No. 02; 2020

special woreda's council is strictly monitored to ensure that each indigenous groups of the region is represented in the council. ${ }^{113}$

In the Nationality Council, however, non-indigenous groups are not represented in the Council according to Honorable Ato Gemechu Arebo, the Deputy speaker of the Council although a lot of them live in the region. The speaker explain the reason: the representation of non-indigenous groups limits the representation chance of the indigenous groups. Secondly, the non-indigenous groups are barred from participation because the region is established for the protection and promotion of the interests of the indigenous groups, not that of the non-indigenous group, who can seek representation in their own regional state. ${ }^{114}$ The deputy speaker confesses, however, that the same approach does not dictate the framing the composition for the regional council. The ruling party (SEPDM/ EPRDF ) assured a very limited avenue for members of the non-indigenous groups to be represented in the council via allowing person form this group to be candidates in the party lists probably to rally the behind its election campaigns. The representation should not be seen lightly because the council is power engine of the vast region as it is espoused with the power to adopts laws, approves socioeconomic development programs and regional budget. ${ }^{115}$ The effect of such inclusive approach by the SEPDM/ EPRDF (i.e. the multiethnic party) is also highly felt at the zonal level of the region. The party assures inclusiveness of non-indigenous groups, for instance, in the city councils in the multiethnic cities of Aleta Wondo and Yirgalem. ${ }^{116}$

All in all to wind up this session, the above proposed quota system for the representation of the nonindigenous groups is line with the level of ethnic consciousness and mobilization held by the people at large. Messay puts this eloquently; ethnic classification and solidarity in the Ethiopian context is not a widespread phenomenon among the population. It is more common among the elites than the ordinary people. Even on the part of the, though it may have changed its stand and takes the ugly form of exclusion, originally it was based on, but initial ethnic in Ethiopia on the party of the political elites was based on, as Berhanu Gutema elucidate the point, in many cases that the major

\footnotetext{
113 The information on the selection procedure for of members of the CoN is received from Honorable Deputy Speaker Ato Gemechu Arebo, during an interview held on April 15/4/2015, 2:00pm-3:00pm (Local Time) Detail information and discussions regarding the purpose and composition of the CoF was obtained by the researcher during his Interview with Ato Gemechu Arebo, Honorable Deputy Speaker of the CoN.

${ }^{114}$ Detail information and discussions regarding the purpose and composition of the CoF was obtained by the researcher during his Interview with Ato Gemechu Arebo, see supra note 114

115 Supra note 111 , p. 13

${ }^{116}$ An interview with W/r Ayelech Ledamo, Honorable Deputy Speaker of the Sidama Zone Council confirms that due to the SEPDM/EPRDF inclusive policy though halfhearted in my view, persons from Amhara ethnic origin serving the party at the City Council level. However, the researcher learned during an interview on April,2015 with informants at the States Council, whose name is kept confidential, even though a number of representative that joined the Regional Council from Benji-Maji ,Keffa and Shaka Zones belongs to Amhara ethnic group, they let alone reflecting the interests of the local Amhara's in the Council ,they do not wish to be identified as Amhara's perhaps because they are encircled by the indigenous groups in the council, who dominate and somehow perceives persons from Amhara ethnic group representatives of the old dismantled regimes. Therefore, they remain passive during their tenure. Therefore, we can say their membership was for lip serves.
} 


\section{International Journal of Education and Social Science Research}

ISSN 2581-5148

Vol. 3, No. 02; 2020

inspirational forces for the ethnic based organizations are the attainment of social, political and economic objective rather than primordial or atavistic drives. In almost all cases, the claims for ethnic mobilization and solidarity have been made in the context of redressing injustices of the past', reclaiming of dignified existence and self-administration, developing of culture and usage of languages which were ignored and barred in the past ${ }^{117}$.

In similar vein Mehari Taddele contends while the justification for the establishment of the very ethno-linguistic based regional state was the demand for equality and freedom from domination, then it is paradoxical not to accept equality for migrant and members of other ethno-cultural communities in the regions, hence after opening more opportunity for the indigenous inhabitants of regional states it is believed that speaking of the federal constitution it become the mandatory stipulation for regional elites to respect the political participation rights of the migrants as minorities in their regional institutions. ${ }^{118}$ From pragmatic point of view, therefore, the accommodation of the interest of the non-indigenous groups should not have to barred in lieu of the fact that the measures to be contemplated in this paper, as hinted above, cannot out vote and outnumber the same intuition harbored by the indigenous groups of peoples. For instance, in this regard take the issue of the quota system to be injected in the federal constitution for the accommodation of the right to representation of the indigenous groups will have to be devised in a way that do not affect the right to representation of the indigenous groups. For this purpose the standard setting shall foresee and single out the minimum and maximum number of seats to be reserved ${ }^{119}$ to the non-indigenous groups in the

\footnotetext{
${ }^{117}$ Berhanu Gutema, 'Restructuring State and Society: Ethnic Federalism in Ethiopia, a PhD Thesis no.8, Submitted to Aalborg University, SPIRIT \& Department of Culture and Global Studies, 2007, Denmark, Retrieved on March 21/2015,Available at https://debteraw.files.wordpress.com/2008/06/berhanugb-ethnicity.pdf ,p.47-48 118 Mehari Taddele, 'the Devolution of power: the Legal and Political Aspects', a paper Presented to Public Discussion Forum for Political Parties, Organized under the auspices of African Institutes for Democratic World, March 2008, United Nations Conference Center, Addis Ababa, , Retrieved on March 18/2015, Available at< http://meharitaddele.info/wp-content/uploads/2012/11/Devolution-of-Power-Mehari-Taddele-Maru.pdf>,p.25-26 ${ }^{119}$ As Florian Beiber maintained stronger groups might, for instance, exert pressure on smaller communities to be satisfied with inadequate representation in a government, whereas the smaller groups might seek to maximize representation in excess to their population share. Reserved seats in parliament are only useful for smaller minorities, which might be excluded from representation, see the details for this, Florian Beiber, 'Institutionalizing Ethnicity in the Western Balkans: Managing Change in Deeply Divided Societies', European Centre for Minority Issues, 2004, Retrieved on March 18/2014, Available at <http://www.ecmi.de/uploads/tx_Ifpubdb/working_paper_19.pdf,>. In the present Ethiopian contexts reserving seats to the non-indigenous groups should take into account those factors because they live scattered throughout the regional states, hence, in the states that follow plurality system, their non-representation is real, therefore, they need some percentage of reserved seats.Moreover, on the part of the indigenous groups fear of domination explains the lower representation of the highlanders in the Gambela and Benishangual Gumuz parliament. See the details concerning the political participation of the non-indigenous group Christophe Vander Beken, Unity in Diversity-Federalism as a Mechanism to Accommodate Ethnic Diversity: the Case of Ethiopia, LIT VERLAG Gmblt and Co.KG Wien ,Zweigniederia, Zurich,2012, p.255, see for the details on the ill sides of plurality election system adapted in Ethiopia, Beza Dessalegn, 'Ethiopia's Ethnic Federalism and the Political Rights of Non-Indigenous Regional Minorities: The Case of Benishangul Gumuz Regional state', an LLM Thesis submitted to Addis Abeba University School of Graduates Studies ,January 2010, P.83-84.
} 


\section{International Journal of Education and Social Science Research}

ISSN 2581-5148

Vol. 3, No. 02; 2020

regional council. Based on this regional constitutions will work out the detail applications of this standard on the composition to be made in their respective city councils.

As slightly hinted in the above, any approach taken with the view to prioritize the group rights of the indigenous groups will do nothing beyond dismantling the constitutional promise affirmed article 38 of the FDRE constitution. This article confirms individual rights to partake in the conduct of public, So now without introduction of second language that most non-indigenous groups are versed with we cannot achieve the constitutional commitment under article 25 that permits equal enjoyment of rights stipulated under the constitution, namely, the right to political participation (i.e. article 38 of the FDRE constitution and article 25 of the ICCPR respectively). Moreover, disenfranchising a large number of the population in most urban areas of the different regional state only results in confining the negative message that the regional state is the sole ownership of the indigenous ones, degrading those not versed with the working language as outsiders. ${ }^{120}$ Therefore, for the seek of facilitating inter-ethnic dialogue in the representative chambers we suggest the introduction of translation services chambers. ${ }^{121}$ into through constitutional upper limits for political participation of migrants even in regions, where the indigenous groups are devoid of overwhelming majority, it is possible to strike the right to political participation of the indigenous groups a with the migrants by introducing Amharic as second, while maintaining the working language of the Regional Government in the Legislative Councils though fixation of the upper limits of seats reserved to the non-indigenous groups in regions, where the former groups only manages to have slight population advantage over the later groups.

\subsection{The Practical Aspects of political participation and Power Sharing in Hawassa City Executive and Representative Assemblies}

\subsubsection{General Background of the Hawassa City Administration: A brief Analysis}

Hawassa City is located in the SNNP Regional State on the shores of Lake Hawassa in the Great Rift Valley; South of Addis Abeba via Debre Zeit $273 \mathrm{Km}$ south of Finfinne (Addis Abeba). Geographically, the City lies between 6054'-7 latitude North and 38 degree 48'-38degree 33'longitudes east. The City bounded by Lake Hawassa in the west, Oromia Region in the North, Wondogenet woreda in the East and Shebedino woreda in the South. The city is economically important and expanding quite rapidly compared to other cities. This is perhaps due to its location as crossroad to Moyalle-Addis Abeba rout and destination centre for most of travellers from many cities/towns located in the Southern part of Ethiopia.

The City administration has an area of $157.2 \mathrm{kms}$, divided into 8 sub-cities and $32 \mathrm{Kebels}$, these eight sub cities are Hayek Dare, menehariya, and Tabore, Misrak, Bahile Adarash, Addis Ketema,

\footnotetext{
120 Yonatan Tesfaye, Institutional Recognition and Accommodation of Ethnic Diversity: Federalism in South Africa and Ethiopia, A PHD Thesis Submitted to University of the Western Cape, 9 June 2008,p.478

${ }^{121}$ Communication problems emanating from the usage of this two language scheme among parliamentarians could be alleviated through translations, see Yonatan Supra note 122, p. 478.
} 


\section{International Journal of Education and Social Science Research}

ISSN 2581-5148

Vol. 3, No. 02; 2020

Hawela-Tula and Mehal sub city. Population wise the City is home to more than 50 ethnic groups, with no ethnic group constituting majority of the City Population, the top five major groups of the region are the Sidama, who, constitutes 46 percent of the population followed by Amhara, Wolayita comes in third place, while the fourth and fifth place are occupied by Oromo and Gurage respectively, while other groups with significant number includes, Kembata, Hadiya, and Tigre. The ethnic composition of the City has been displayed in the table below.

Administratively, the city was under the jurisdiction of the Sidama zone until 2002; the city administration including Kebeles administrations were ruled by individuals from the Sidama ethnic group; thus Sidama language was a working language for administration. However, as per the States Council decision in 2002 the administration of the City was taken away from the Sidama Zone. ${ }^{122}$ Though not acceptable to the Sidama elites the ruling party SEPDM/EPRDF has attempted to explain the reason behind this move. The reason was disseminated to the Cadres through the module entitled as "How to Lead Our Metropolitan City?" The module announced that the corrupt, rent-seeking and politically inefficient nature of the Sidama officials hindered the development of the 'metropolitan city'. The ruling party propagated in order to tackle this problem, there new policy would be "opening-up policy" in which every ethnic group is entitled to administer the city. ${ }^{123}$

The re-organization of the City was, however, already commenced before 2002 decision. At the end of the late 1990s, the government began to consider the re-organization of the municipality with the suggested solution to take Hawassa out of Sidama Zone and to be designated thereafter as municipality to be administered by the officials from all ethnic groups in the town. ${ }^{24}$

Leaving aside the thorny issue whether the taken a way of the City from the Sidama zone jurisdiction was motivated on the part of SEPDM/ERPDF to narrow the power base of the Sidama's (i.e. from their ethnic constituencies), thereby deflating their ambition to state hood, but one thing is clear; the plights of the majority of the population of the city, who are ethnically mixed and non-Sidama, is saved because they are not versed with Sidama language ${ }^{125}$.

The State Council proclamation namely,Procl.No.103/2006 has complemented the 2002 decision of the regional government. The proclamation had widened the co-decision making power of the ethnic residents of the City. Now, the introduction of Council-Mayor system has vested in the city council the final authority on urban issues. The creation of this autonomous city administration offers non-

\footnotetext{
122 Supra note 118,p.213-214

${ }^{123}$ Kinkino kie, 'The Right to Form One's States under Ethiopian Federation: the Case of Sidama People', an LLB Thesis Submitted to Hawassa University, School of Law, June 2013, Retrieved on March 16/2015,Available at <http://www.academia.edu/5649642/The_Right_to_Selfdetermination_Under_the_Ethiopian_Federation_A_Sidama_ Peoples_Test_Kinkino_Kis_thesis-1>,p.93

124 Supra note $123, \mathrm{Id}, \mathrm{p} .75$

125 Supra note 118, p213-214
} 


\section{International Journal of Education and Social Science Research}

indigenous minorities, who are numerically majority than the Sidama's an important avenue of political participation ${ }^{126}$.

Structure wise the City administration is organized under legislative, executive and the judiciary organs. Accordingly, the city was established as the Council-Mayor system of urban administration. It is structured into two tiers of administration: the Municipal (City) Administration at the top and the Kebele Administration at the sub-unit of administration, which is in turn structured into three organs namely, Kebele Council, Kebele Chairperson, and Kebele Social Courts. At the top governess level we find the Mayor and the Deputy Mayor, who are respective Head and Vice Head of the Mayor Office together with other Heads and Vice Heads of the various Departments of the City make-up the City Executive Council. Amid this government structure, the ruling party Political Apparatus exists to coordinate, supervise and monitor the impalement of Governmental and Party plans; where in this regard the Public Relation, the Political and Social Organization Affaires Advisors to the Mayor are the most powerful and indivisible hands behind the curtain. The lowest government structure, the Kebele is governed by the Kebele Administrator, Deputy Administrator, Political Affair Advisor of the Administrator (Youth and Sport Affair), Justice and Security Affairs, Health Affair, Women and Children Affair, Trade and Industry Affair, which they together constitutes Kebele Cabinet. The Kebele Council is composed of representatives elected from among residents of that Kebele.

\subsubsection{The Political Participation of Minorities in Hawassa City Council and the Executive Branches}

\subsubsection{The Protection of Individual Rights}

As verbatim copy of the FDRE constitution significant part of the SNNP constitution is dedicated to individual rights, where among others the very pertinent rights to ensure political participation, for instance the right to non-discrimination in employment, the right to elect as well as the right to stand for election, the right to information, the right to acquire property are all affirmed under the same constitution. ${ }^{127}$ Most informants agree that following the governance of the city via mayor-council system, the basic individual rights of both the indigenous and non-indigenous groups is observed. This may explain the pouring of investors to the city to the various fronts of the Ethiopia territory. The latter group of people owns most of the city's luxuries hotels and other business establishments. $^{128}$

\subsection{The Individual's Right to Employment in the City Civil Service Sector}

The practices of the City Civil Service also largely go in line with the right to employment affirmed under Art.32 of the SNNP constitution. As data obtained through interview reveal that non-

\footnotetext{
${ }^{126}$ Supra note 95,p.47

${ }^{127}$ Art.10 of the 2001 SNNP Constitution unequivocally declares that human and Democratic rights shall be respected.

${ }^{128}$ During an interview held with Endale Temesegen, Deputy Head of the Harare Kebele Administration on April 16/04/2015, 9:00pm-10: pm (Local Time) that up until 2002 there was grievance in terms of access to land, employment and access to education for the non- indigenous groups, but know the major participant in the City economic activates are the non-indigenous peoples, this is because they have stared harbor the feeling of ownership of the city.
} 


\section{International Journal of Education and Social Science Research}

requirements of Sidamidigna language to be employed as civil servants in the City government offices have largely opened the opportunity for non-Sidama ethnic groups to get employed in the sector. That is why currently their percentage share in that sector, according to the 2006 compiled statistics from Hawassa city civil service department, has reached $38.01 \%$. Previously, however, the usage of Sidamigna language in the civil service was severely detrimental to the right to employment of the city residents. In those periods (i.e. from 1991-2002) though Sidama's are numerically smaller than the non-indigenous groups, they were dominant in the civil service sector owing to nepotisms in the requirements of civil servants. As the leader of an Eder confirms in employment, it was accustomed to give priority to individuals from Sidama ethnic group. ${ }^{129}$ Obviously, this appeared attractive for parents of non-Oromo/Sidamas or mixed Oromo's/Sidamas from neighboring Oromia or Sidama Zone to teach their children's in Hawassa city in believing that they their children's will get job there. The composition still falls under domineering effects of the Sidama's. The group though encompasses 46 percent of the City population; it occupies 62 percent of the sector at expenses of the non-indigenous groups, who account 54 percent of the City population. As per an interview with a Sidama's elite this composition is right because the Sidama have self-determination right over the city. ${ }^{130} \mathrm{In}$ lieu of these facts it is suggested that the regional council shall ensure the new accommodative devises through legal schemes rather than dependent political will as the current approach is telling.

On the part of the Sidama's it is the writer observation that in the long run their current dominant share is not secured in light of job seeker coming from adjacent Oromia and Sidama Zones Cities. Hence, taking into account those multitude factors amide the past experience of exclusion from the civil service sector, the way forward in the multiethnic city is to stipulate for just and equitable representation of all residents in the civil service sector without losing professionality requirement so as the civil service sector will properly reflects the ethnic structure of the City. Of course, in this regard, while affirming the necessity to ensure multiethnic nature of the city, it strict application of professionality system may not be always to stick with rather other options could be surface as to the

\footnotetext{
${ }^{129}$ Supra note 118 ,p. 213

${ }^{130}$ During an interview with Ato Kasahun Karisa, Human Resource Officer in Human Resource Core Work Process at the Hawassa city civil service department, on April 16/04/2014, 3:00pm-4:30pm (Local Time) contended that the numerical domination of the Sidama is not because of discrimination to the non-indigenous groups; rather it is due to the location of the city in the center of Sidama's zonal peripheral limits. Moreover, W/rt Tsehaye Ali, a Team Coordinator of Human Resource Information, Statistics and Supply Core Work Process, assured that to her knowledge that all requirements are 'merit' based. Moreover, she revealed that the "Civil Servant Complaint Hearing and Investigation Core Work Process "is a body authorized to monitory and investigate if there is any complaint regarding the employment process. Honorable Deputy Speaker of Sidama Zone Council, W/r Ayelech Ledamo, also confirms the same by arguing that there is no roam for Sidama's to get jobs through back doors, but she confesses that in non-merit based positions Sidama civil servants could be counted in several numbers. In an interview with Informants, whose name kept confidential in April 2015 , contended that the reason lays to the political calculation of the SEPDM/EPRDF. They contended that in order to appease the Sidamas quest for internal secession, persons belong to the Sidamas, where rewarded with jobs in the Sector. They corroborate this by making reference to the holding of the Regional Presidency position by Sidama's since the inception of the Region. See the details for internal secession of Sidamas, Kinkino, supra note 124.
} 


\section{International Journal of Education and Social Science Research}

ISSN 2581-5148

Vol. 3, No. 02; 2020

table as an option. If the civil service is not mosaic of the diversity of the polity, as scholars argue the state will be devoid from receiving the necessary support from all key groups and be held to be discriminatory at the level where most citizens are affected (i.e. in the civil service bureaucracy. ${ }^{131}$ This will be much helpful for the sector to give due cognizance for the multitude interest of the diversified groups ${ }^{132}$. As opposed to the strict commitment for proportionality scheme as suggested before, the lesson from Bosnia and Herzegovina is instructive. The 2002 Civil Service Law of requires the sector to be generally reflective of the multi ethnic composition of the state, ${ }^{133}$ thereby giving some flexibility in the requirement process.

Though the author is un-abled to solidity information concerning the composition of the policy department in Hawassa city, it is highly recommended for the city policy to exhibit the diversified nature of the town as far as reflecting diversity is the subject matter. As the law enforcing organ it its composition should be considered carefully. This is because it is associated with increased trust by minority citizens in the police staffs if the sector features diversity as the experience of Macedonia. ${ }^{134}$ Unfortunately, even at federal level, the reading of the prembular statement of the 2002 Federal Civil Service Law reveal that diversifying the sector is neglected matter in opposition to the commitment the federal constitution made under article 39(3).

\subsubsection{The Right to Political Participation and Power Sharing at the City and Kebele Councils}

As can be observed from the Procl.No.103/2006 that the establishment of urban governance closures to the local people facilities the self-rule rights of the people. ${ }^{135}$ The political participation of the public is a sine qua non for the realization of the self-rule rights of city residents; hence, in this regard save to say: participation and power sharing are, therefore, the means to this through the conduit of city and kebele councils as well as on the city and kebele executive organs.

Political participation and power sharing in those institutions in case of Hawassa viewed from one angle concerns all of the indigenous ethnic groups of the region, who are recognized by the SNNP constitution as such, because the city is their capital city; ${ }^{136}$ on the other hand based on the elucidation of the rights of indigenous groups by Kymlicka: indigenous groups, who are the first settlers to the area have the right to self-determination over their traditional territory; hence Sidama's have the right to self-rule over their traditional constituency, namely Hawassa City, which they are

\footnotetext{
${ }^{131}$ Supra note 120, p.7

132 Oleh Protsyk and Konstantin Sachariew, 'Ethnic Data Collection: The Case of the Civil Service in Eastern Europe, European Centre for Minority Issues', Retrieved on March 16/2015,Available at< http://www.ecmi.de>

${ }^{133}$ Florian Bieber, 'Power Sharing and Democracy in Southeast Europe', Taiwan Journal of Democracy, 2013, p.139

${ }^{134}$ Florian Bieber, 'Power Sharing and the Implementation of the Ohrid Framework Agreement', Friedrich Ebert Stiftung , Skopje, 2008, Retrieved on March 17/2015, Available at< http://www.fes.org.mk> ,p.31

135 See the prembular statement of Proclamation No.103/2006

${ }^{136}$ The 56 indigenous groups, to whom self-determination rights residues under 39 of the 2002 revised constitution of SNNP Regional State arguable, are entitled to the right to have a say on the governance of the city. Similar rights shall extends to the other non-indigenous groups based on the FDRE constitution article 39 (3). This is because as per Van der Beken the stipulation provides a right to be exercised non-territorial basis, See for this, Supra note 123, p.41-43
} 


\section{International Journal of Education and Social Science Research}

ISSN 2581-5148

Vol. 3, No. 02; 2020

eagerly seeking toady, as an interview with Sidama elite depict the feeling that the principles of ethnic federalism and the Constitution grant them a right to use and promote their language, to have their own self-administrative constituency in the Hawassa City ${ }^{137}$.

Viewed from those broad angles, therefore, the City institutions are required to balance power sharing and political participation rights of both the non- indigenous groups, who according to the Regional Council decision of 2002 have the right to partake in the administration of the City as well the indigenous groups of the region, who are subsumed together with migrants outside of the region under the name non-indigenous groups for mere convince by this paper, who also have the right to representation in the City as per the prembular statement of the SNNP constitution on one hand and on the other hand the right of the indigenous groups namely, Sidama's right to self-rule over their traditional City.

The parts ensuing this will assess whether the political participation in the City and Kebele Councils. However, worth to mention from the outset that the total control of the city executive council by Sidama's opposes inclusive approach deployed by the regional council, not to mention the grievance aroused due to the exclusion of the other ${ }^{138}$ multiethnic residents of the city ${ }^{139}$ when the city was under the Sidama zone for ten years. Moreover, on the other side of the coin the decision of the Regional Council to take away the administration of the City from the Sidama's Zone strictly speaking from the legal point of view has deprived the Sidama's the right they are supposed to enjoy on the ground of their indigenousness like the right to protect and promote their language in the City, except the case of the 30\% quota currently reserved to them by Procl.103/2006, whose continued application in the future is at stake if opposition parties controlled the seats of the City Council. In short the later statement is implying that Sidamas have deprived the rights to reflect their identity in the city institutions and the land. In to some have hailed the opening up policy of the regional states because it avoided the notion of minority rule over the majorities without totally depriving the Sidama's right to political participation as the quota system is the living witness ${ }^{140}$.

\subsection{In the City and Kebele Councils}

As mentioned clearly in the above parts both indigenous and non-indigenous ethnic groups have a stack in the governance of the city. Therefore, governmental institutions of the city are required

\footnotetext{
137 Supra note 124, p.73

138 Supra note, 118, p. 213

139 Supra note 124,p.77

140 Some scholars criticize 'Proc.No.116/2006 of the Oromia Region Urban Governance law on the basis that the proclamation through reserving a total of 70 percent city to the Oromo's has narrowed the space for the right of other groups to compete for the city and Kebele Councils. Moreover, this law has narrowed down the significance of the participation of the non-indigenous groups in the city councils because they lost the leverage to ensure that the Mayor elected is sympathetic to their cause because the election is the discretionary power of the regional President. In Southern Region, however, the Mayor shall be appointed by the residents' of the city in exercising their self-rule though the City Council, who is tied interims of accountability to the city residents. The Sidama's are beneficiary from the concept of 'mirror representation' as the Mayor is going to be selected from the indigenous groups, see the detail for this, see for this Yonatan and Christophe, Supra note 95 , p.47-48
} 


\section{International Journal of Education and Social Science Research}

ISSN 2581-5148

Vol. 3, No. 02; 2020

accommodate the right to equitable political participation of all ethnic residents of the city. In Hawassa city, the city Council was established in 2000 (E.C) following the re-structuring of the city administration and now it is found on the second round with the number of the Council determined to be 176 , where 16 members, during the time is paper is written, are directly joined from the Sidama Council allegedly to fill the 30 percent quota reserved to the Sidama's. Those members joining from the Sidama Council, who are mostly residents of the City and serving at the City Executive Council have double function, namely they are required to attend the secessions of both the Hawassa City and the Sidama Zone Councils. ${ }^{141}$ This scheme poses the question of accountability of those members. To be more specific, to whom these persons will become accountability in instance were Sidama residents of the City hold different view than the Sidamas living across the Sidama Zone peripheries.

When we see the composition of the Council it largely resembles the multiethnic feature of the City. For instance, in the second round of the City Council the ethnic compositions are as follows; Sidama 130 (73.8\%), Wolayita 13 (7.3\%), Amhara 10 (5.6\%), Oromo 5 (2.85),Gurage5(2.8\%), Tigray 4 (2.8\%),Hadiya 3(1.7\%), Selte,2(1.1\%), Kembata1(0.6\%), Tembaro 1(0.6\%), Dawaro 1(0.6\%). The ethnic composition of the Council, save to say runs paradox to Procl.No.103/2006 Art.16. Because article under sub (3) leaves wider avenue for political participation of the non- indigenous groups through leaving $70 \%$ of the City Council. Leaving only 46 seats (23\% of the Council seats) to the non-indigenous groups, who account more than $55 \%$ of the city population; has severely curtailed the democratic participation of the majority of the city population in the Council. Moreover, the addition of 16 seats to the Sidamas is not in tandem with the reason for the reservation of the $30 \%$ quota because the reason behind the introduction of quota system was intended to minimize the outvoting of the indigenous groups by the non-indigenous groups a fair balanced approach, but now the data is telling this: the Sidama's are overly represented in the council in direct opposition to the spirit of the re-structuring of the city administration.

As it stands now the legitimacy of the Council as well as the Executive Council that emanates from it, is questionable because it failed to be the reflection of the 'will of the City residents' as whole due to the disproportionate representation of the majority residents in the Council in opposition to their large sized population. This negates the core principle of procedural democratic election owning to the production of an assembly that does not reflect the size of the electorate. In short this tantamount to depriving one person one vote principle ${ }^{142}$ because election constituencies are drawn disproportional to the size of the population of the Kebele; where according to the official explanation the largest and smallest Kebels are entitled to have an equal 5 have representatives in the Council despite of the variation in number of populations each Kebele is cherished with. ${ }^{143}$ By this scheme Tulla Town Sub City that constitutes of one Kebele with the smallest population size

\footnotetext{
${ }^{141}$ An Interview conducted by the author with Ato Negalegn Alemu, Information and Documentation Core Process Coordinator at the Hawassa City Council on 18/04/2015,8:00pm-9:00pm ( Local Time ).

142 Supra note, p.143

${ }^{143}$ An interview with Ato Negalegn Alemu, Supra note, 172
} 


\section{International Journal of Education and Social Science Research}

ISSN 2581-5148

Vol. 3, No. 02; 2020

(i.e. 1026) has managed to send one representative less than Misrak Sub-city, a kebele that can send two representatives though the population size of the later kebele is far more than the previous kebele population size two. The number of population in Misrak sub city 32688. ${ }^{144}$

In Matyus v. Slovakia, the Human Rights Committee prohibits aforesaid kind of disparities population size and number of representatives per those constituencies, where in this regard it clearly affirmed that this tantamount to violation of artcile 25 of ICCPR unless justifiable reasons otherwise the it had the aim of minorities' right to political participation in the elective parliament (i.e. this termed as deviations from absolute vote The Apportionment of equal seats to both rural and urban constituencies is detrimental to the representation of the urban dwellers because instead of this, $r$ parity). ${ }^{145}$ Therefore, the way for is to organize electoral constituencies pro rata to numeric size. This scheme will not deter Sidama's from holding considerable seats in the city council though the one man one vote is introduced. This is because the Sidama community had numerical superiority over the non-indigenous groups in the rural Kebels. This refers to the overwhelming numerical majority possessed in the 11 rural Kebeles that account to $36 \%$ of the City population; not to mention the quota system reserved to them ${ }^{146}$ ( i.e. they will enjoy additional 16 votes ). If one man on vote principle is adapted as it should have been, then the non-indigenous groups, who are majority in the heart of the city comprising $64 \%$ of the population across 21 Kebeles of the City, ${ }^{147}$ there upon improve the current minority position they are stacked. But, now the apportionment of equal number of seats to both rural and urban constituencies is detrimental to the representation of the urban dwellers because, this is owning to the fact that population wise the size of the two differs; the urban areas where the urban dwellers constituting large size of population are obligated to send equal number of representatives despite of the small number of inhabitants living in the rural areas.

Based on the above fact legal prescription shall be deployed to rectify the disproportional representation of the urban dwellers. The more troublesome issue in regard to representation is the case of the small sized minorities, which includes the like of the Silte, Gedio, Keffa, Harare, Halaba, Gofa perhaps, because of their small sized population are left out of the composition of the Council, if schemes were instilled that ensures their participation then those "minorities will feel that they are

\footnotetext{
${ }^{144}$ See the details for the distribution of population across the 8 Sub-Cities of Hawassa and the name of the Kebels found in each Sub-Cities, the' Socio-Economic Profile for 2006 E.C', Prepared by Hawassa City Administration, Finance and Economic Development Department, Jan.2015 G.C ,p.11,14-16

145 Supra note 19,p.145

${ }^{146}$ Apart from the information inked on the 'Socio-Economic Profile 2006 E.C' on the theme of population size of city, the Rural Kebels, many informants' beliefs (i.e. Adjacent rural Kebels) constitutes the majority of the Sidama population due to their indigeneity over the area, while the so-called 'Mehal Ketema is primarily occupied by the multiethnic groups (Mete's).

${ }^{147}$ The population distribution of the City across rural and urban Kebeles can be easily analyzed from the data annexed to this paper. The distribution of the people across some urban kebeles also speak for itself that the non-indigenous groups are numerically dominant than the indigenous group. In this regard some of representative Kebeles for this are Addis Gebeya, Andienet, Wukero, Nigatkokeb, Harare, and Addis Abeba.
} 


\section{International Journal of Education and Social Science Research}

active and equal members of the city ${ }^{148}$. . Therefore, despite of those worrisome issues internal minorities of the city are endowed with representation in the Hawassa city council, thereafter conferred a chance to ensure that the execution of federal and regional laws, policies and standards takes into account their diversified needs. Moreover, apart from the multi ethnic composition of the council, the educational status of members to the Council accords an opportunity to undergo a wellinformed debate (i.e. because there are members with an excellent educational status ; one third degree holder, 15 second degree holders, 71 first degree holders, 18 diploma degree holders ).

A part from some worrisome issues of representation, here are additional problems; firstly, the quota system for the Sidama's is not warranted via higher laws like regional constitution of the SNNPR because if the opposition parties come to power they can easily reverse the reserved seats. Secondly, there is no election law perhaps a one modeled after the federal election law, but takes into account the goals of the regional states (i.e. Empowerment of the indigenous society of cities across the region). Due to the legal gaps exhibited here opposition parties can run for election even in the cities allocated to the Sidama community in the absence of a clear law that bars such endvour. In short the election law does not deter parties from running for election on the ground that their lists of candidates are non-inclusive of the indigenous groups ${ }^{149}$. For instance, election constituencies characterized by multiethnic -compositions like the case of Yirgalem city in SNNPR state where the non-indigenous groups hold population advantage over the indigenous group Sidama, if citizenship based party's like CUD,UDJP, Blue Party runs for election for the city council there, then the Sidama's will be dismembered form the council; needless to mention this because the council will be filled by candidates of those parties, whose nominees are from the multiethnic groups without conferring specially attitudes to the representation of any ethnic community including the Sidama's because this parties are citizen based parties.

Without the right kind of electoral law designed for the empowerment of the indigenous society in multiethnic cities, what saves the plights of this group of peoples seems to be the political calculation

\footnotetext{
148 Hodžić, Supra note 11 ,p.13-14

${ }^{149}$ Ato Yehalashet Abebe insists that the mandatory prescription for parties running to the City Council to have members representing the indigenous groups, would run against constitutional rights to stand for election because citizens are entitled to partake on the conduct of public affairs through party channels irrespective of whether the party is constitutive of members representing the indigenous groups; if we do so and bar those parties then this tantamount to denial of the right to political participation of citizens, who stand behind this parties. He affirmed, however, the position of the election law on the requirement of knowledge of the working language of the region to run for Regional Legislative Council does not contravene the constitutional right to political participation. He reason out that the stance of the law has striked out the balance between the self-rule rights of 'Nations, Nationalities and people's and the individuals right's to stand for election. In order to ensure the political participation of individuals, while maintaining group's right for self-rules permitted individuals to stand for election as long as they are versed with working language of the region irrespective of their ethnic affiliation. His stand seems to express that if local language was not maintained as working language, instead if Amharic was introduced as co-official language alongside the regional language then the indigenous groups right to self-rule will be endangered because non-Amahars, owing to lesser extent of formal education they will effectively lose access to the state apparatus because those, who are well versed with this language easily exceed them , see the detail for this Yonatan, Supra note 121, P.401-402
} 


\section{International Journal of Education and Social Science Research}

ISSN 2581-5148

Vol. 3, No. 02; 2020

parties running for an election; for the ruling party this seems to be an easy task as its affiliated party in grass roots level are ethnically affiliated parties. The party does not have problem interims of nominating candidates from the indigenous groups; the opposition too may follow similar footing with the view to win the heart and mind of the indigenous society.

Therefore, the way forward will be for the regional councils ( i.e. it should be noted that the designing of institutions is within the constitutional space of regional governments ${ }^{150}$ ) is to design legal stipulations that requires, whom ever managed to legally seize majority seats in the City Councils to reserve 30 percent of its seats to members representing the indigenous group, thereafter whether the citizen based, multiethnic or nationality based parties wins majority seats in the Council, their quotas remain intact. As per interview conducted with members of the election board stipulating such kinds of requirement by the electoral law would be considered as meddling in the internal affairs of parties, hence it up to parties to arrange themselves in concordance with the prescriptions of the regional Procl.No.103/2006.

In regard to the non-representation of the small sized internal minorities; one particular measure shall be contemplated. This referees to the need to devise consultative procedures. This is due to as per expert's advice: along institutionally securing the political participation of the small sized minorities it is imperative to devise consultative procedures under the ambit of the city council so as those nondominant minorities will minimize the effects of outvoting by the large sized ethnic groups of the city. This will facilitates their consultation on draft local ordinances, administration of urban lands, on decisions to levy and revise tax and other hosts of matters that fall under the power of the City Council as stipulated under Procl.No.103/2006. The FCNM is instructive for his endvour. The document stipulate under Art.15 for states parties to the Convention to take necessary measures for the effective participation of persons belonging to national minorities in public affairs, in particular those affecting them. ${ }^{151}$

In order to improve power sharing and political participation of minorities in the city councils, as elucidated above, has been seriously curtailed. Therefore, in order to rectify this federal as well as the SNNP Regional States constitutions (the case in point) could foresee for a number of legal stipulations. On the part of the FDRE constitution giving cognizant to the multiethnic compositions of the cities it shall map out a country wide strategy that serve as a reference standards for the Regional Council to strike out the balance between the right to political participation as well as the right to promote and protect once own identity by both the indigenous and non-indigenous groups. It seems, however, the regional states seems to be incapable of shouldering the responsibility to devise such legal prescription because as Yonatan elucidates, regional majorities are rarely found to be sympathizers for the cause of intermingled minorities their minorities that life amid them. ${ }^{152}$ They

\footnotetext{
150 Supra note 110, p. 5

151 Supra note 57, p.15

152 Yonatan Tesfaye, 'Federalism, the Subnational Constitutional Framework and Local Government: Accommodating Minorities within Minorities', Perspectives on Federalism, Vol. 4, issue 2, 2012,p.89
} 


\section{International Journal of Education and Social Science Research}

ISSN 2581-5148

Vol. 3, No. 02; 2020

often impose their language and culture on regional minorities without even noticing the presence of large sized population, who are not versed with the language of the dominant group. Dominantly the task should fall on the shoulder of the federal constitution, which is equally empowered to gear its efforts for the respect of human rights listed under chapter three of the constitution. Such renaissance move shall commence from the outset changing the plurality election system that is ill suited to the contexts of the cities, which harbors several scattered minorities throughout the city into that of proportionality electoral system. ${ }^{153}$

The PR electoral system adapted, for instance, in Bosnia has enabled ethnic groups to acquire representation in parliament in proportion to their numbers ${ }^{154}$.If proportional representation system is introduced it forces local political officers to ensure that their lists of candidates' compress both the indigenous and non-indigenous groups because the numerical thresholds specified for each ethnic groups shall be respected in the parties list of candidates.

For the purpose of setting numerical threshold, consideration could be accorded to foreign experience (i.e. those countries identified as successful interims of establishing representative assembly based on numerical criterion at the municipalities (perhaps parliamentary) level. One is to consider the case of Bosnia-Herzegovina. In Bosnia, the 2008 Election Laws reserves one seats for minorities in municipal councils when in those municipalities minorities constitute more than 3 percent of the population and if the number exceeds 3 percent, then at least two seats were to be guaranteed. Moreover, there exist a practice in cases where the number of persons belongs to minorities found below 3\%, and then local governments provide one or even two reserved seats for them. ${ }^{155}$

In Similar vein, according to the Constitutional Law on the Rights of Minorities, at Parliament level, Croatia provides guaranteed representation for national minorities. For instance under Art.19 (3) national minority with a share of more than $1.5 \%$ in the total population of the Republic of Croatia shall be guaranteed at least one and not more than three parliament seats in accordance with the law regulating the election of MPs. Under the same vein Art.19 (2) Members of national minorities are entitled to elect at least five and not more than eight MPs in special constituencies in accordance with the law regulating the election of MPs. While, assenting to this detailed mechanism of representation, it should not be forgotten the necessity to ensure that the suggestion will not offset the previously determined quota for the Sidamas as indigenous people. Moreover, for those minorities, who cannot benefits even out of the proportional system due to their smallest size (i.e. though even if a party may runs in their names he cannot secure minimum number of votes that excel the electoral threshold set forth ) reservation of seats shall contemplated no matter how their population size is small. The reason for the latter case can be made like this; reserving seats are

\footnotetext{
153 supra note 19 ,p.144

${ }^{154}$ Yonatan Tesfaye, 'Ethnic Identity and Institutional Design: Choosing an Electoral System for Divided Societies', Retrieved on March 16/2015, Available at <http: //heinonline.org.>

155 Supra note $24-25$
} 


\section{International Journal of Education and Social Science Research}

ISSN 2581-5148

Vol. 3, No. 02; 2020

indispensable owing to the fact that ethnic based opposition parties mostly opt to run for election in the name of those minorities with large size, neglecting the smaller once ${ }^{156}$.

In order to entrench the rights of minority in the council alongside numerical representation and seats assurance schemes; the decision making process should be amended in selected cases; hence, this notifies the introduction of the system of a double majority, known as' the Badinter majority in Macedonia'. This procedure requires a majority of all MPs, as well as those the separate meeting and voting of those, who declare themselves to represent all non-dominant groups on matters that affects minorities. ${ }^{157}$ In regard to decision making process, taking into account indigenous position of the Sidama people, decisions among others on the appointment of the Mayor of the city shall secure not only the assent of the majority of the council members, rather should secure the will of the Sidama representatives holding a separate vote ${ }^{158}$. This facilitates inter-ethnic dialogue between the majorities occupying the floors of the city councils and the Sidama's acting alone because the appointee is required to secure the wills of both parties.

\subsection{The Right to Power Sharing and Political Participation in the Kebele Councils}

When we come to Kebele Councils all of the 32 Kebeles have managed to have their own Kebele Councils with uniform number of compositions, namely 200 Kebele Council members though sometimes this number may fall during the duration of the Councils due to absence of remunerations for members of the Council, consequently depriving the voice of their ethnic groups in the Councils. Though exact number of population has not been gathered due to absence of structured data's at each kebele level; one thing is certain as per interview held with officials of kebele and city council ${ }^{159}$; kebele councils are the widest institutional avenues for political participation and power sharing of both the indigenous and non-indigenous groups. The corroboration to this claim is to be found on the total composition of members of the Kebele Councils across the 32 Kebeles of the City. Accordingly, the Kebele Councils in toto across the city peripheral limits in its Second Round, consists of 3553 Sidama representatives, 936 Wolayita, Amhara 798, Oromo 369, Kembata 144,, Gurage 261, Tigre 130, Hadiya 144, Gamo 52, Dawaro21, Silte 15, Keffa 13, Gofa 7, Gadeo 6, Harari 3, Koyera 3,Halaba 1, Burgi 1, Tembaro 1 .In sum 19 ethnic groups are represented across the 32 Kebeles. ${ }^{160}$

\footnotetext{
156 Id,p.26

${ }^{157}$ Martin Brusis , 'The European Union and Interethnic Power-sharing Arrangements in Accession Countries,' European Journal on Ethnopolitics and Minority Issues ,p.24

158 Under the proclamation that sought to settle the governance the mayor as stipulated in Art.18 (1,) he/ she is required only to garner the support of majorities of members of the council( i.e. here the referred law is proclamation No.103/2006) without in consideration of minorities in the council .

${ }^{159}$ Regarding the ethnic composition of the city and kebele councils is gathered during the discussion the writer had with members of the Information and Documentation Core Work Process of the city, as well as interviews held with deputy head of the Harare kebele administration, speaker of Addis Abeba kebele council, all agree that kebele councils. ${ }^{160}$ The information on the ethnic composition of the city council is obtained from the Hawassa City Council Information and Documentation Core Work Process
} 


\section{International Journal of Education and Social Science Research}

ISSN 2581-5148

Vol. 3, No. 02; 2020

The corroboration to the above assertion is in order here: for instance, let us hammer on Kebeles that features mostly the non-indigenous groups, in Harare kebele as an example the composition displays the following; Guragies have 64 seats, Amhara's 57, Oromo's 25, Gamo's 2, Sidama's 8, Hadiya's 2 seats; concerning their leaders the Head Speaker of the Council is from Gamo, Deputy Speaker is comes from Amhara. Here the kebele executive council is, which is supposed to be drawn from this kebele council features the following:- the head of the kebele administration is wolayita, the deputy administration is Oromo, who have also considerable number of population in the Kebele, the Amhara ethnic group, who wields are the largest population in the kebele manages to have representatives in the executive council commensurate to its population size: for example the security and justice affair is Amhara, education and health affair is from amhara, trade and industry is drawn from amhara, youth and sport affair is Amhara too, but the women's and children's affair position goes to the Guragies'. ${ }^{161}$

\subsubsection{2 in the City and Kebele Executive Organs: a City Geared under a Homogenous Executive}

Expect in the case of kebele executive, the composition of the city executive council does not follow the spirit of the SNNP constitution affirmed under the priambular statement namely consolidation of democracy and the advancement of shared interest in the multi ethnic city, the city executive council is overwhelmingly held by members of a single ethnic group. If all ethnic residents of the City are to bear benefits and burdens equally, then the multiethnic composition maintained in the council should have been replicated at the executive council level. Moreover, Amharic being the working language of the city, political participation and power sharing could have been easily facilitated in the executive council too, where most residents of the city are converse with ${ }^{162}$. Here the figures speak this: the city executive council is over whelming drawn from a single ethnic group (i.e. in toto from the heads and their deputies currently leading 17 governmental departments, we find that 17 leaders out of the total 21 executives' council members) ${ }^{163}$ are representatives of Sidama ethnic group. This pose the question whether the city legally speaking belongs to the Self-rule of Sidamas or the multiethnic residents of the city as aspired in the new regional proclamation.

${ }^{161}$ The information on the ethnic composition of the Harare kebele council and the kebele cabinet was obtained from W/r Asenakech Alemu, speaker of the kebele council during an interview on April 19/2015, 3:00pm-3:50 pm (Local Time )

${ }^{162}$ According to policy document of the ruling party (EPRDF), either willingly or forcefully most members of the Ethiopian polity are well versed with Amharic language, see for this Fiseha Haftetsion, choosing working language in multi ethnic nations: rethinking Ethiopia's working language policy retrieved on May 31/2015, Available at $<$ http://www.aigaforum.com/articles/Paper-on-Ethiopia-Language-Policy.pdf , >, p.15

${ }^{163}$ The information on the composition of the executive council of the city was obtained from credible informants, whose name is kept confidential during an interview on April, 2015 on Hawassa city. The official record on the composition of the City Executive was not made accessible to the writer of this paper by both government and the political wing of the SEPDM/EPRDF. Among the government officials interviewed, but failed to give the information during the writing of this paper, includes, chief advisor to the mayor Ato Belayeneh Teshom (head of Hawassa city mayor's office ), Ato Belay Bekele, (head of the city administration), and Ato Wateso Wedesa (the head of Hawassa city SEPDM/EPRDF Branch Office. 


\section{International Journal of Education and Social Science Research}

ISSN 2581-5148

Vol. 3, No. 02; 2020

The political structure of the city too displays the same features; the mayor himself and his political and public relation affaires advisory, who also serve in other capacity namely, the head of Hawassa city SEPDM/EPRDF branch office, whose power full and invincible hand extends to the nomination of the city executive councils, all belongs to the Sidama ethnic group. The occupation of the Mayor seat by the Sidamas is plausible in light of the city procl.103/2006 that provides the mayor to be appointed from the indigenous group (i.e. see article 21(1)). In lieu of the indigenous characteristics of the Sidama's the measure is compatible with international standards too. But in the face of the SEPDM/ EPRDF internal regulation it is not mandatory for the Chair Person of the local branch office to come from the indigenous group.

In similar avenue to respond to multiethnic compositions of the city executive council foreign experiences shall be consulted just like what had been suggested in the case of the city council. In lieu of the homogenous executives now maintained at the city level unlike the kebele levels, the need for consociational arrangements that institutionalize the participation of minority representatives in the joint governance of public affairs of the city is highly felt. This is because all minority groups as per the new proclamation espoused are entitled to partake in the joint governance of the city tanks to the mayor council governance system instilled by the proclamation.

In nutshell there are reasons dictating consociational scheme in the city executive level. One being fears the Sidama's harbors (i.e. not to lose the sight on how the city is being governed, which they deem it as it belongs to their traditional land) in light of the opening up policy followed by the city the Regional Council for the authorization of the rule of the city by multiethnic groups. They did express their angers vehemently in an incidence that leds to confrontation in May 2002, which is commonly referred to 'the Looqqe Incidence' that ended in tragedy. ${ }^{164}$ Therefore, there shall be instilled legal scheme that ensures the Sidama's fair share in the power distribution, especially in light of the indigenous make-up of the population. From the other side of the coin, implanting power sharing arrangement is mandatory owing to the past exclusion this group of people felt when the city was under the Sidama zone. The type of justice the non-indigenous groups seek in this transitional period (i.e. from being under the domineering effects of a single ethnic group to co-governance of the city ) is the non-repetition of the past systematical exclusion from public life, where the medication to this is to be found in recognizing their right to share power in the current process of democratization .It is held that in this multi-ethnic city the exclusive control of the key administrative post by the Sidamas may have a negative impact on the outsiders. Therefore, if legally backed codecision making is enrooted, then the various groups a apart from avoiding their concerns they may go to the extent of benefiting; Florian Beiber maintained the advantages of power sharing make ups: power sharing promotes cross-cutting Cleavages; it can cut across ethnic lines and help mitigate the pervasiveness of ethnic identity in deeply divided societies; it is a common tool to increase

${ }^{164}$ Supra Note $124,75-78$ 


\section{International Journal of Education and Social Science Research}

ISSN 2581-5148

Vol. 3, No. 02; 2020

interethnic co-operation at local level, reduce disparities focuses in preventing ethnic differences being reinforced by other inequalities ${ }^{165}$.

In light of the problems exhibited in the composition of the executive council in the Hawasa, here we will continue dwell on foreign experience relevant to our case; for example, the Croatian Law on the Rights of Minorities apart from ensuring representation of minorities in elected Councils, it also envisages minority participation in the executive organs. In this regard Art.22 (2) (3) granted the right to representation in the administrative bodies of self-government units for national minorities pro rata to size of the minority in the locality the executive bodies ${ }^{166}$. Therefore, in account of the merits of power sharing for avoiding ethnic conflicts and tis advantage for facilitating inter-ethnic dialogue and cooperation ${ }^{167}$ Thus, in the face of those powers sharing arrangements schemes the contexts of Hawassa City, interethnic cooperation and avoidance of feature conflicts, it is advised that city executive shall be drawn from different groups; the enabling factor among others are medium sized of all the ethnic groups dwelling in the city. ${ }^{168}$

In toto as far as the need to build all inclusive government structure is concerned (i.e. the demand for Power sharing) in the contexts of the Hawassa city executive council is advised to at least commence from those populations identified as having significant number as the power sharing philosophy dictates. This reference groups such as Sidamas, Amahars, Wolayitas, Oromo's, Guragies Tigres, Hadiyas, and Kemebatas. However, in the power sharing schemes Sidamas should be conferred with more posts in the executive as owing to their indigenous nature. In the this regard, the executive council positions vice to heads could be reserved to the non-dominant minorities, who wield small size population as the experience of Kosovo States executive compositions illustrates ${ }^{169}$. Moreover, domestic practices in Dire Dawa are also illustrative of how to share power in the executive. In Dire Dawa administration, like Hawassa a home to multiethnic groups, have envisaged a practices to share power between the two historical inhabitants of the area (i.e. the Ethiopian Somali and Oromo's), without total wiping out the right to political participation of other non-indigenous groups, who have the right to participate in the city institutions as per the City Charter because the Charter affirms unequivocally that the City belongs to the residents. ${ }^{170}$ In line with this to appease the intuitions of the two indigenous groups, who agitate for power and ownership of the city, ${ }^{171}$ the Administration has apportioned the executive seats on 40-40-20 scheme. Under his power sharing arrangement, Ethiopian Somali people democratic party (ESPDP)occupy $40 \%$ of the executive

\footnotetext{
165 Supra note 120 , p.12-13

166 The Croatian Law on the Rights of National Minorities, Official Gazette no. 155/2002 ,Zagreb , December 13, 2002, Retrieved on May 31/2015 <http://www.vsrh.hr/CustomPages/Static/HRV/Files/Legislation_Constitutional-Law-onthe-Rights-NM.pdf>

${ }^{167}$ Supra note, 40,264

168 Ibid

169 Supra note 55, p.134

170 The Dire Dawa City Administration Charter (i.e. Procl. No.416/ 2004) in its priambular statement confer selfgovernment power on the residents of Dire Dawa City.

171 Supra note 98,p.163
} 


\section{International Journal of Education and Social Science Research}

ISSN 2581-5148

Vol. 3, No. 02; 2020

offices and the rest $60 \%$ goes to EPRDF; i.e., which EPRDF is entitled to allocate the remaining $40 \%$ to Oromo people democratic organization / OPDO/EPRDF and 20\% to the rest 2 parties constituting EPRDF namely, ANDM and SEPDM.

\subsubsection{Enhancing the Ethno-Symbolic Attachment of the Sidamas in their Traditional City}

The Sidamas being indigenous to the area have the right to enhance their language and culture in the city. Moreover from pragmatic point of view the flow of many ethnic groups in the area risks the promotion and protection of Sidamigna language in the area. This is supported by the intuition of Sidamas to serve the public through Sidamigna as many informants, whose name kept confidential testify to the trustworthiness of this allegation. Hence, this demands schemes to nurture the development of their language in the city, while at the same time keeping the demands of the nonindigenous groups to be get public service in a language that most of them can understands. There are foreign experiences helpful for those purposes. For instance, according to the Frame work agreement in Macedonia, any ethnic community as long as its numerical number constitutes $20 \%$ in a given municipalities, it is authorized to receive service in its language, there upon conferring that language second language statues next to Macedonia, which is the official language in the entire territory. Similarly in Montenegro, the Law on Rights and Freedoms of Minorities provides a right to members of national minorities for official usage of their language in the units of local governance where they constitute majority or considerable portion of the population. ${ }^{172}$ Therefore, in order to strength the tie the Sidama had in their historical periphery, they be accorded with the right to use and receive documents in Sidamigna language in the city governmental institutions through adapting Sidamigna a second official language next to Amharic at least for the time being owing to resource constraints and feasibility issues. ${ }^{173}$

The afore said countries experiences also dictate the same for the Regional Government to authorize the usage of Sidamigna as second language in the official works of the city government. This is owing to the numerical thresholds the Sidamas enjoy (they account $46 \%$ of the population of the City) they warranted in demanding the introduction of Sidamigna as second language. Let us skim how other countries responded to such intuition. In the case of Macedonia, for instance, if the ethnic community comprises $20 \%$ of the municipal community, then it is entailed to use its language as second language. In Montenegro Law on National Minorities provides that the percentage of the members of national minorities against the total number of citizens should amount to 15 percent in

\footnotetext{
172 Tamara Kaliterna ( ed., ) 'Minorities in Montenegro Legislation and Practice', a Report prepared by Miroslav D. Janković ,Edina Hasanaga Čobaj, Youth Initiative for Human Rights, Retrieved on March 17/2015 Available at $<$ www.yihr.or,>,p.8

${ }^{173}$ Francois Grin, 'Linguistic Human Rights as a Source of Policy Guidelines: A critical Assessment', Journal of Sociolinguistics 9/3, 2005: 448^460, P.454-455
} 


\section{International Journal of Education and Social Science Research}

ISSN 2581-5148

Vol. 3, No. 02; 2020

order for them to be allowed to officially use their language and script in the units of local governance. ${ }^{174}$

In addition to this measures, with view to further entrench the symbolical attachments the Sidamas had over Hawassa, based on the federal standards this paper suggested to be espoused, the regional government could rethink as pursuant to the experience of Montenegro; the naming of public authorities, municipalities, settlements, squares and streets, institutions, business and other companies and toponyms as well as writing in the language and script of the Sidamas. In Montenegro national minorities that form major or considerable portion of population are entitled enjoy those rights pursuant to the Law on Rights and Freedoms of Minorities minority. ${ }^{175}$

\section{Part VI}

\subsection{Conclusion and Recommendation}

Based on the new version of the right to internal self-determination member state to UN charter are required to secure the participation of the public in the instance where they are dealing with the socio-economic and political decisions. In this regard, they are duty bound to make sure the inclusion of persons belonging to minorities.

$>$ The inclusion of minorities in this respect is adored for the fact that it assures the taking into account of the concerns of minorities while passing decisions by the majorities controlling

In particular in reference to Ethiopia, where at both federal and regional level numerous minorities' exists, the FDRE constitution has envisaged not only the rights to political participation of minorities both in collective and individual aspects, but it also has enshrined ample tools necessary to realize those rights.

$>$ The legal tools among others in this regard includes the entrenchment of the rights to receive and impart information, the right to assembly, demonstration, the right to vote and to be elected, which are a rights indispensable for the enjoyment of other hosts of democratic and human rights enshrined under Chapter three FDRE constitution, the right to representation both at federal and states institutions for nations, nationalities and peoples of Ethiopia, the right to nurture once own language and identity.

Intimately linked to above there is puzzle of thought exercised by scholars of the area that whether the rights inculcated in the same constitution which can only be exercised together with others ( i.e. groups rights) extend to those minority groups, who lives intermingled with those ethnic groups espoused with the rights to self-determination. In this regard the reason for naming them minority emanates from the truth that some regional constitutions clear empowers a few/ single group as owners of the regional territory, while relating the rest of the others as new comers (i.e. perhaps by some authors as non-indigenous group or in the Amharic acronym

\footnotetext{
${ }^{174}$ Miroslav D. Janković and Edina Hasanaga Čobaj, 'Minorities in Montenegro Legislation and Practice', Youth Initiative for Human Rights, Retrieved on March,15/03/2015, Available at< www.yihr.or> , ,p.8

175 Id,p.9
} 


\section{International Journal of Education and Social Science Research}

ISSN 2581-5148

Vol. 3, No. 02; 2020

' $\square \mathrm{D} \cap$ '); echoing a message that they cannot claim group rights like the right to political participation as well as the right to promote and protect once language and identity even in the instance where the so-called non-indigenous group of people commands considerable size of the regional states ( i.e. in several of the cities located within the regional states of the regions named after the titular groups the numerical size of the non-indigenous groups out number and out vote the so-called indigenous groups in particular in multiethnic cities of the country like the case of Shashemen, Yirgalem, Dilla, Jimma and other towns ). In this regard authors air out opposing views on the whether the FDRE constitution is meant to totally wipe the non-indigenous groups from the fruits of testing the rights mentioned under article 39(2,3). Some contended, it is not the spirit of the constitution to bar the non-indigenous groups form enjoying those rights that can be exercised on non-territorial bases including the rights to political participation in the states institutions and the right to promote and protect one's own culture and language. In any case the constitution is vague as far as the inquiry is whether groups rights are only reserved to those so far identified by the respective regional constitutions as bearers of the regional states, therefore, minorities who have perhaps established their own regional states somewhere, but now living intermingled with the majority (indigenous group) barred from dun for groups rights, save the case of individual rights

Nexus to the last statement the record of SNNP Regional Council (i.e. the study area of this paper) in the fourth round illustrates that political participation of non-indigenous groups has been effectively curtailed.

$>$ Despite of the afore said controversy, some matters are lucent; the exclusion from testing the benefits of group rights, in particular, participation rights and promotion of once own identity conflates with the basics of the Ethiopian people's values (living together aspects) the democratic rights of Ethiopian citizens to participate in the affairs of public conduct is affirmed under Art.38 of the FDRE Constitution. Moreover the path followed stands in paradox to the underlying reason for the introduction of the rights to self-determination in as much as it is meant to guarantee the avenues for indigenous society to advance the right to autonomy so as its culture, socio and economic policies without putting others in total depriving of the enjoyment of the same kind of rights as underpinned in international law.

A part from the constitutional muteness, the prime factor for disfranchisement of non-indigenous groups from power sharing the as evident in many regions of Ethiopia is working language requirement to run for the state's legislative and city councils; which this fact would not allow us to go without notifying the need to introduce schemes helpful in striking the balance between the rights to political participation of citizens' vis-v-vis the right to self-rule of the titular (indigenous) groups'(named in the context of this paper federal standard) .

$>$ The non-existence of federal standard for the aforementioned purpose derailed the endvour of the multiethnic residents, in particular in the case of Hawassa City, for power sharing and political participation as well as the intuition to get public serves in a language they can comprehend. This represents the respective quest of both the Sidama ethnic group identified in this paper as 


\section{International Journal of Education and Social Science Research}

ISSN 2581-5148

Vol. 3, No. 22; 2020

indigenous society owning to possession of indigenous character and other urban dwellers encompassing different groups.

The federal standard suggested here in above ( the standard is supposed to be aligned with the upheavals multiethnic cities facing in account of the location within the territorial limits of a group as per the new federal dispensation, who claims self-determination rights and those intermingled minorities harboring the intuition for the promotion and protection of their identity as well as for political participation rights despite of the former group stance to enjoy those rights in the exclusion the latter group of persons) is required to strike a balance between the right to political participation and the endvour to nurture once own identity by the indigenous group of people and the disempowered ethnic residents avouch for the same rights of the city. Here the touchstone alluded should permit the introduction of second language widely spoken by the marginalized minorities and devise too power sharing scheme without voting the desire of the indigenous group to enjoy similar rights.

Therefore, in lieu of the problem faced by the Hawassa city, relying on the federal standard the regional state should espouse power sharing among ethnic residents of the city, while in this respect, providing many concessions to the indigenous group (here the point is Sidamas should be entitled with several executive seats including the mayor should be drawn from this ethnic group). In similar vein, Sidamigna should be inculcated as second working language. Moreover, the naming of public authorities, municipalities, settlements, squares and streets, institutions, business and other companies and toponyms in Sidamigna language should be rethought by the legal stipulation for this end to be provided by the SNNPR legislative council.

$>$ A further suggestion to the federal standard, it shall provide mandatory schemes of power sharing in the city council prorate to the population size of minorities. This road map shall also be aligned and contextually implemented by the regional legislative council for the composition of Hawassa city council, while similarly reserving considerable seats to the representatives to the indigenous group. To aid this endvour, the composition of the city council shall be designed on the basis of proportionality electoral system (i.e. here the federal electoral law shall be first changed into form plurality system into proportionality electoral system), while similarly for those ethnic minorities of the city commanding very small size of population then a separate system of reserved seats where candidates only representing this group of people can compete shall be instilled while maintaining the antecedent quota system enrooted by the decision of the regional legislative chamber for the seek of the Sidama's.

$>$ As currently, the Sidama people's right to form once own regional states is loading and looming largely, the fate of the city will be much of concern. But, I contend this: in light of the multiethnic nature of the city, the city shall be administered by city charter proclamation to be enacted by the regional legislative council in par with the experience of the countries mentioned here in this paper (i.e. of course foreign experience has been suggested in this paper in place it is found to be pertinent) in the contexts it is deemed to be very essential to the city ethnic make ups. This law (termed in this paper federal standard and believed to be responsive to the multiethnic features of several cities as far as the intuition to exercise group rights is concerned) owning to 


\section{International Journal of Education and Social Science Research}

ISSN 2581-5148

Vol. 3, No. 02; 2020

less probability for swift modification and surgery to be made on the federal constitution till then it shall be farmed by the SNNPR legislative council, where later on the federal constitution shall take instructive lesson if it deems, when the time rips for amendment.

A part from responding to the multiethnic nature of the city, the regional law shall strives to guaranty as much autonomy; for instance, interims of fiscal freedom and rare instance of upward accountability of the city to be organized on the basis of city-mayor governance system to the regional legislative council.

As far as the future status and accountability of the city is concerned in case if referendum is to be held for the seek of determining the Sidama's quest for self-determination rights, then the city residents too in that case be scheduled to hold their own separate referendum on whether to remain on the SNNPR State or to be chartered city and fall under the domain of the federal government or become capital city of the new tenth regional state too be inaugurated soon as Sidama people quest for self-determination seems to be on the edge. In any case this paper harbors strong affirmations that the facts underground needs to be respected as prevailed in Hawassa city (i.e. the city is home to the Sidama people and other ethnic residents ) irrespective of the result of the city level referendum, therefore in account of this, legal barometer shall be designed, of course, by the SNNPR legislative chamber worth of satisfying the indigenous nature of the Sidama people and the accompanied rights flowing out of this character and the ethnic dwellers of the city, who are the beauty marker of the city and economic back bone of the city. 


\section{International Journal of Education and Social Science Research}

ISSN 2581-5148

Vol. 3, No. 02; 2020

\begin{tabular}{|c|c|c|c|c|c|}
\hline 1 & Sidama & 84,709 & 73,937 & 158,646 & 46.23 \\
\hline 2 & Amhara & 24,728 & 27,376 & 52,104 & 15.18 \\
\hline 3 & Wolayita & 24,788 & 24,430 & 49,218 & 14.34 \\
\hline 4 & Oromo & 8,940 & 8,670 & 17,610 & 5.13 \\
\hline 5 & Guragie & 7,577 & 7,081 & 14,658 & 4.27 \\
\hline 6 & Kembata & 4,807 & 4,430 & 9,237 & 2.69 \\
\hline 7 & Hadiya & 2,417 & 2,249 & 4,666 & 1.36 \\
\hline 8 & Tigrie & 2,218 & 2,177 & 4,395 & 1.28 \\
\hline 9 & Others & 16,312 & 16,141 & 32,453 & 9.46 \\
\hline & Total & 176,599 & 166,576 & 343,175 & \\
\hline & $\begin{array}{l}\text { Name of the } \\
\text { Ethnic } \\
\text { Community }\end{array}$ & Male & Female & $\begin{array}{l}\text { Total } \\
\text { Population of } \\
\text { the ethnic } \\
\text { community }\end{array}$ & $\begin{array}{l}\text { Share of the Ethnic } \\
\text { community from } \\
\text { Total Population of } \\
\text { the City in Percentage }\end{array}$ \\
\hline
\end{tabular}

1. Source: The Socio-Economic Profile of Hawassa City, 2006 E.C, Population by Ethnic Group (Hawassa City). 


\section{International Journal of Education and Social Science Research}

ISSN 2581-5148

Vol. 3, No. 02; 2020

\section{Chart II}

2. The Ethnic and Sex Composition of the Civil Service Department of the Hawassa City (for the Year 2007, E.T)

\begin{tabular}{|c|c|c|c|c|}
\hline \multirow[b]{2}{*}{ No. } & \multirow[b]{2}{*}{$\begin{array}{l}\text { The Name of the Ethnic } \\
\text { Groups }\end{array}$} & \multicolumn{3}{|c|}{ Number of Workers } \\
\hline & & Men & Women & Total \\
\hline 1 & Amhara & 336 & 483 & 819 \\
\hline 2 & Sidama & 2174 & 1607 & 3781 \\
\hline 3 & Oromo & 155 & 157 & 312 \\
\hline 4 & Wolayita & 329 & 217 & 546 \\
\hline 5 & Burgi & 5 & 3 & 8 \\
\hline 6 & Kembata & 60 & 63 & 123 \\
\hline 7 & Hadiya & 20 & 18 & 38 \\
\hline 8 & Gurage & 105 & 106 & 211 \\
\hline 9 & Tigre & 76 & 82 & 158 \\
\hline 10 & Dawaro & 10 & 14 & 24 \\
\hline 11 & Gofa & 10 & 13 & 23 \\
\hline 12 & Gamo & 13 & 5 & 18 \\
\hline 13 & Halaba & -- & 1 & 1 \\
\hline 14 & Silte & 5 & 7 & 12 \\
\hline 15 & Gedio & 1 & 1 & 2 \\
\hline
\end{tabular}




\section{International Journal of Education and Social Science Research}

ISSN 2581-5148

Vol. 3, No. 02; 2020

\begin{tabular}{|l|l|l|l|c|r|}
\hline 16 & Wereji & & 1 & 1 & 2 \\
\hline 23 & Basketo & & 1 & ---- & 1 \\
\hline 24 & Koyera & & 3 & $-\cdots--$ & 3 \\
\hline 25 & Afar & & & & 6093 \\
\hline Total & & & 3371 & & \\
\hline
\end{tabular}

\section{BIBLIOGRAPHY}

\section{Non-Electronic Sources}

\subsection{Books}

Assefa Fiseha, Federalism and the Accommodation of Diversity in Ethiopia: a Comparative Study, $1^{\text {st }}$ edn. Nijmegen: Wolf Legal Publisher, 2006

Fasil Nahum, Constitution For Nation of Nations: The Ethiopian Prospect, $1^{\text {st }}$ edn., the Red Sea Press ,Inc. Princess Road, Lawrenceville ,1997

Janda, K., M.Berry, J. and Goldman, J. the Challenges of Democracy: Government in America, $8^{\text {th }}$ edn. Charless Hartford.

Kymlicka, w., Multicultural Citizenship: A liberal Theory of Minority Rights, $1^{\text {st }}$ edn. Clarendon Press. Oxford, 1995

Lijphart, A., Thinking about Democracy: Power Sharing and Majority Rule in Theory and Practice, $1^{\text {st }}$ edn. Routledge, New York, 2008

Vander Beken, C., Unity in Diversity-Federalism as a Mechanism to Accommodate Ethnic Diversity: the Case of Ethiopia, LIT VERLAG Gmblt and Co.KG Wien , Zweigniederia, Zurich,2012

Will Kymlicka, Politics in the Vernacular: Nationalism, Multiculturalism and Citizenship. Oxford University Press, Inc., New York, 1st ed., 2001

\subsection{Journal Articles}




\section{International Journal of Education and Social Science Research}

ISSN 2581-5148

Vol. 3, No. 02; 2020

Abera Degefa, 'The Scope of Rights of National Minorities under the Constitution of Federal Democratic Republic of Ethiopia', Series on Ethiopian Constitutional Law, Vol. 1, AAU Printing Press, Ababa University, 2000

Tamerate Delelegne, 'The legal Basis for Self-Rule in Ethiopian Cities', Journal of Ethiopian Law, Vol.26, No.1, 2006

\subsection{Thesis Papers}

Beza Dessalegn, 'Ethiopia's Ethnic Federalism and the Political Rights of Non-indigenous Regional Minorities: The Case of Benishangul Gumuz Regional state', Addis Abeba an Un Published LLM Thesis Submitted to School of Graduates Studies, January 2010

Solomon Emiru ,'The Human Rights Commission and its Role in the Protection of Minority Rights: A comparative Study', an Un Published LLM Thesis Submitted to the Institutes of Federalism and Legal Studies ,Ethiopian Civil Service University

Yonatan Tesfaye, Institutional Recognition and Accommodation of Ethnic Diversity: Federalism in South Africa and Ethiopia, A PHD Thesis Submitted to University of the Western Cape, 9 June 200

\subsection{Domestic Laws}

Government of Oromia National State

Proclamation No.1116/2006, a Proclamation to Amend Proc. No.650/2003 of Urban Local

Proclamation No.103/2006, a proclamation To Provide for the Revised Cities Proclamation of the Southern Nations, Nationalities and Peoples

The constitution of the People's Democratic Republic of Ethiopia; Proc No.1/1995 Negarit Gazette 1st year No.1,21 August 1995

The Revised SNNP Regional Constitution Approval Proclamation No. 35/ 2001 November 12/ 2001 The Transitional Period Charter of Ethiopia, Negarit Gazette, $50^{\text {th }}$ Year, 1991, No.1.

\section{Electronic Sources}

\subsection{Books}

Lamprianou, L., 'Contemporary Political Participation Research: A Critical Assessment', in K.N. Demetriou (ed.), Democracy in Transition: Political Participation in the European Union, Heidelberg, New York, Retrieved on March, 15/2015,Available at <www.springer.com/cda/content/.../cda.../9783642300677-c1.pdf?.2013, > 


\section{International Journal of Education and Social Science Research}

ISSN 2581-5148

Vol. 3, No. 02; 2020

Leary,'B. O., the Logics of Power Sharing Consociation and Pluralist Federations' in Marc Weller and Barbara Metzger (ed.), Settling Self-determination Disputes: Complex Power-sharing in Theory and Practice, Martinus Nijhoff, Leiden/ Boston, 2008, Retrieved on March 18/2015,Available at < http://www.brill.com/settling-self-determination-disputes, >

Wheatley, S., Democracy, Minorities and International Law, $1^{\text {st }}$ ed., Cambridge University Press, Cambridge, 2005, Retrieved on March 18/2015 ,Available at $<$ http://www.research.lancs.ac.uk/portal/en/publications/democracy-minorities-andinternational-law\%2817d9f6c9-8041-48fb-aecf-7c814ad0e668\%29/export.html,>

Margaret Moore, 'The Territorial Dimension of Self-Determination' in Margaret Moore ( ed. ), National Self-determination and Secession, $2^{\text {nd }}$, Oxford University Press , Great Clarendon Street, New York, United States, Retrieved on May 31/2015Available at $<$ http://ukcatalogue.oup.com/product/9780198293842.do,>

Helen O'Nions, Minority Protection in International Law: the Rome of Europe, $1^{\text {st }}$ ed., Ashgate Publishing Limited, Hampshire, England, 2007, Retrieved on May , 31 /2015,Available at< http://www.ashgate.com,>

\subsection{Journal Articles}

Bieber, F., 'Power Sharing and Democracy in Southeast Europe', Taiwan Journal of Democracy, 2013

Brusis, M., 'The European Union and Interethnic Power-sharing Arrangements in Accession Countries,' European Journal on Ethnopolitics and Minority Issues in Europe, 2003

Christophe Van der Beken, 'Federalism, Local Government and Minority Protection in Ethiopia: Opportunities and Challenges', Journal of African Law, December 2014,

Grin, F., 'Linguistic Human Rights as a Source of Policy Guidelines: A critical Assessment', Journal of Sociolinguistics 9/3, 2005: 448^460,. 2005

Kincaid, J., 'State Constitutions in the Federal System', 496, Annals of the American Academy of Political and Social Science, March 1998

Lyon, A., 'Between the Integration and Accommodation of Ethnic Difference: Decentralization in the Republic of Macedonia', Journal on Ethnopolitics and Minority Issues in Europe Vol. 11, No. 3, 2012.

Malloy, T.H., 'National Minorities between Protection and Empowerment: Towards a Theory of Empowerment', Journal on Ethnopolitics and Minority Issues in Europe, Vol. 13, No 2, 2014 , 


\section{International Journal of Education and Social Science Research}

ISSN 2581-5148

Vol. 3, No. 02; 2020

Patten, A., 'Political Theory and Language Policy', Vol. 29 No. 5, October 2001 691-715, Sage Publications

Regelmann, A., 'Introduction - Minority Participation in Estonia and Latvia', Journal on Ethnopolitics and Minority Issues in Europe, Vol. 13, No 1, 2014

Villiers, B. d., 'Protecting Minorities on a Non-Territorial Basis-Recent International Development,' Beijing Law Review, 2012,

Wheatley, S., Non-Discrimination and Equality in the Right of Political Participation for Minorities, Journal of Ethnopolitics and Minority Issues in Europe, 2002

Yonatan Tesfaye and Christophe Vander Beken, 'Ethnic Federalism and Internal minorities: The Legal Protection of Internal minorities in Ethiopia', African Journal of International and Comparative Law, 21.1, 2013

Yonatan Tesfaye, 'Ethnic Identity and Institutional Design: Choosing an Electoral System for Divided Societies'

Yonatan Tesfaye, 'Federalism, the Subnational Constitutional Framework and Local Government: Accommodating Minorities within Minorities', Perspectives on Federalism, Vol. 4, 2012

\subsection{Articles}

Beiber, F., 'Institutionalizing Ethnicity in the Western Balkans: Managing Change in Deeply Divided Societies', European Centre for Minority Issues, 2004, Retrieved on March 18/2014,Available at <http://www.ecmi.de/uploads/tx_lfpubdb/working_paper_19.pdf, >,

Bieber, F., 'Introduction, in Political Parties and Minority Participation', Friedrich Ebert Stiftung, Skopje, 2008, Retrieved March on 30/2014, Available at <http://www.fes.org.mk/pdf/Political\%20Parties\%20and\%20Minority\%20Participation.pdf>

Bieber, F., 'Power Sharing and the Implementation of the Ohrid Framework Agreement', Friedrich Ebert Stiftung, Skopje, 2008, Retrieved on March 17/03/2015 Available at <http://www.fes.org.mk/pdf/OFA english.pdf $>$

Bieber, F., Balancing Political Participation and Minority Rights: The Experience of the former Yugoslavia, European Centre for Minority Issues, 2002/2003, Retrieved March, 30/2014, Available at <http://pdc.ceu.hu/archive/00001819/01/Bieber>

Danielova, D. M. 'Roma as Unique Cultural Minority: the Impact of Communism and Democratization on Roma in Eastern Europe', Durham theses, Durham University, Retrieved March on 18/2014, 2011Available at $<$ http://etheses.dur.ac.uk/875/ > 


\section{International Journal of Education and Social Science Research}

ISSN 2581-5148

Vol. 3, No. 02; 2020

Fiseha Haftetsion, Choosing Working Language in Multi Ethnic Nations: Rethinking Ethiopia's Working Language Policy, Retrieved on May 31/2015, Available at <http://www.aigaforum.com/articles/Paper-on-Ethiopia-Language-Policy.pdf, >

Frowein D. h.c. J.A and Bank R.., 'the Participation of Minorities in Decision-Making Processes', Expert study on Issues Relating to the Protection of National Minorities , Max-PlanckInstitute for Comparative Public Law and International Law, Heidelberg, November 2000, Retrieved on March 17/2015, Available at <https://www.coe.int/t/dghl/monitoring/minorities/6_resources/PDF_DH$\underline{\text { MIN\%282000\%291_en.pdf }>}$

Good win - Gill, G. S., 'Free and Fair Elections, Inter-Parliamentary Union', Geneva, 2006, Retrieved on March 30/2015 Available at <http://www.ipu.org/pdf/publications/free\&fair06e.pdf>

Hodžić, E. 'Political Participation of National Minorities in Local Governance in Bosnia and Herzegovina: State of the Art, Prospects and Ways Forward', Analitika - Center for Social Research, Sarajevo, 2011, Retrieved March on 19/2015, <www.analitika.ba >

Human rights and election, a Handbook on the Legal, Technical and Human Rights Aspects of Election', Professional Training Series No.2, United Nation, New York, 2001, Retrieved on March '18/2014, Available at r <http://www.ohchr.org/Documents/Publications/training2en.pdf $>$,

Independent Expert on Minority Issues, 'Report of the independent expert on Promotion and Protection of all Human Rights', The UN Human Rights Council, January 2010,New York, Retrieved on March 17/2015 Available at <www2.ohchr.org/english/issues/minorities/expert/>,

Janković M. D. and Čobaj, E. H., 'Minorities in Montenegro Legislation and Practice', Youth Initiative for Human Rights, Retrieved on March, 15/03/2015 Available at< $\underline{w w w . y i h r . o r}>$,

Kaliterna, T., (ed., ) 'Minorities in Montenegro Legislation and Practice', a Report prepared by Miroslav D. Janković ,Edina Hasanaga Čobaj, Youth Initiative for Human Rights, Retrieved on March 17/03/2015, Available at< www.yihr.or $>$

Lena Krook, Mona. and Z. O'Brien, D., 'The Politics of Group Representation Quotas for Women and Minorities Worldwide', April 2010, Retrieved on March 17/2014, Available at < www.mlkrook.org/pdf/krook_obrien_10.pdf> 


\section{International Journal of Education and Social Science Research}

ISSN 2581-5148

Vol. 3, No. 02; 2020

Margaret Moore, 'The Right of Indigenous Peoples to Collective Self-determination', Retrieved on May 31/2015 Available at < http://ecpr.eu/Filestore/PaperProposal/c6f67564-8402-444f8e34-b76c31b1c3b2.pdf>,

Mehari Taddele, 'the Devolution of power: the Legal and Political Aspects', a paper Presented to Public Discussion Forum for Political Parties, Organized under the auspices of African Institutes for Democratic World, March 2008, United Nations Conference Center, Addis Ababa, Retrieved on March 18/2015, Available at < http://meharitaddele.info/wpcontent/uploads/2012/11/Devolution-of-Power-Mehari-Taddele-Maru.pdf>

Petrusevska, T., (ed.)'A guide to Minorities and Political Participation in South-East Europe', A Compilation of Conference Papers Presented at a Regional Conference held in Skopje on 1011 March 2008, Common Values and the King Baudouin Foundation, 2009, Retrieved March,19/2014, Available at <http://www.kbs-frb.be/uploadedFiles/KBSFRB/05\%29_Pictures,_documents_and_external_sites/09\%29_Publications/PUB_1854_Min oritiesPoliticalParticipationSEE.pdft >

Protsyk, O. and Sachariew, K., 'Ethnic Data Collection: The Case of the Civil Service in Eastern Europe, European Centre for Minority Issues', Retrieved on March 17/03/2015Available at< http://www.ecmi.de>.

Tarr, A., 'Subnational Constitutions and Minority Rights: A Perspective on Canadian Provincial Constitutionalism', 2008 Retrieved March 15/2015 available at <http://camlaw.rutgers.edu/statecon) >

Van der Beken, C., Federalism in the Contexts of Extreme Ethnic Federalism: the Case of Ethiopia's Southern Nation and Nationalities and People's Region, Verfassung und Recht in ubersee, 2013

\subsection{Thesis Papers}

Berhanu Gutema, 'Restructuring State and Society: Ethnic Federalism in Ethiopia, a PhD Thesis no.8, Submitted to Aalborg University, SPIRIT \& Department of Culture and Global Studies, Denmark, Retrieved on March 21/2015, Available at <https://debteraw.files.wordpress.com/2008/06/berhanu-gb-ethnicity.pdf >

Danielova, D. M. 'Roma as Unique Cultural Minority: the Impact of Communism and Democratization on Roma in Eastern Europe', Durham theses, Durham University, , 'A Social Resource Model of Political Participation: Mass Media Use, Social Capital, and Political Participation', A PHD Thesis Submitted to Cornell University, January 2006, 


\section{International Journal of Education and Social Science Research}

ISSN 2581-5148

Vol. 3, No. 02; 2020

Retrieved on March 21/2015,Avaliable at <http://dspace.library.cornell.edu/bitstream/1813/2551/1/dissertation-Eunjung\%20Lee.pdf>

Shimels Demissie, 'Arrangement and Inter Governmental Fiscal Relations of Capital Cities with their National Governments: The Case Study of Addis Ababa City Administration', an LLM Thesis Submitted to Addis Abeba University, School of Graduate Studies, December 2010, Retrieved on March 21/2015, Available at <http://etd.aau.edu.et/dspace/bitstream/123456789/3064/1/Shimels\%20Demissie.pdf>

Wondwossen Wakene, Self governing Addis Ababa, the federal government \& oromia: bottom lines and limits in self governance December, an LLM Thesis Submitted to Addis Ababa University ,School of Graduate Studies ,Addis ababa, December 2010, Retrieved on March $17 / 2015$, Available <http://etd.aau.edu.et/dspace/bitstream/123456789/2636/1/wondwossen\%20wakene.pdf>

\section{Foreign Laws and International Instruments}

- Art 27 of the International Covenant on Civil and Political Rights (ICCPR),UNGA Resolution 2200 The Transitional Period Charter of Ethiopia, Negarit Gazette, 50 ${ }^{\text {th }}$ year,1991,No.1. A (XX) of December 1966

- The Croatian Law on the Rights of National Minorities, Official Gazette no. 155/2002, Zagreb , December 13,Reriveid on May 31/2015 <http://www.vsrh.hr/CustomPages/Static/HRV/Files/Legislation_Constitutional-Law-onthe-Rights-NM.pdf>

- United Nations Declaration on the Rights of Persons Belonging to National, or Ethnic, Religious and Linguistic Minorities, UN.GA. Res.47/135, 18 December 1992.

\section{Domestic Laws}

Proclamation No.532/2007, a Proclamation to Amended the Electoral Law of Ethiopia, Negarit Gazeta, 13 ${ }^{\text {th }}$ Year,No.54, Addis Ababa, $25^{\text {th }}$ June,2007,Retrieved on March 17/2015 <http://www.electionethiopia.org/en/images/stories/directives/Proclamation/532.pdf.>

\section{Interviews, Annexes and Others}

1. An Interview with Ato Gemechu Arebo, Honorable Deputy Speaker of the SNNP Regional States CoN

2. An Interview with W/r Ayelech Ledamo, Honorable Deputy Speaker of the Sidama Zone Council

3. An Interview with Ato Mulugeta Halo, Chair Person of the Legal Affairs Standing Committee in the SNNP Regional States Legislative Council

4. An Interview with Ato Ayenekulu Gohastebah, Information Officer at the SNNP Regional State Legislative Council, Information and Documentation Core Work Process

5. An Interview with Endale Temesegen, Deputy Head of the Harar Kebele Administration 


\section{International Journal of Education and Social Science Research}

ISSN 2581-5148

Vol. 3, No. 22; 2020

6. An Interview with Ato Kasahun Karisa, Human Resource Officer in Human Resource Core Work Process a at the Hawassa City Civil Service Department

7. An Interview with W/rt Tsehaye Ali, the Human Resource Information, Statistics and Supply Core Work Process Coordinator at the Hawassa City Civil Service Department

8. An Interview with Ato Wondemu Semehone, Speaker of the Addis Abeba Kebele Council

9. An Interview with Ato Negalegn Alemu, Information and Documentation Core Process Coordinator, at the Hawassa City Council

10. An Interview with Yehalashete Abebe, member of the Election Board Hawassa Zuria and Sidama Zone Constituency Branch Office

11. An Interview with Ato Wateso Wedesa, the Head of Hawassa City SEPDM/EPRDF Branch Office.

12. An Interview with Ato Belayeneh Teshom, Chief Advisory to the Hawassa city Mayor, at the Hawassa City Mayor Office

13. An Interview with Ato Belay bekele, the Head of the City Administration)

14. An Interview with W/rAsenakech Alemu, Speaker of the Harare Kebele Council

Retrieved on March 18/2014, 2011, Available at <http://etheses.dur.ac.uk/875/>

Kinkino kie, 'The Right to Form One's States under the Ethiopian Federation: the Case of Sidama People', an LLB Thesis Submitted to Hawassa University, School of Law, June 2013, Retrieved on March 16/2015 Available at < <http://www.academia.edu/5649642/The_Right_to_Selfdetermination_Under_the_Ethiopian _Federation_A_Sidama_Peoples_Test_Kinkino_Kias_thesis-1>Lee, E. 